\title{
Financial Firm Bankruptcy and Contagion
}

\author{
Jean Helwege $\mathrm{a}^{\mathrm{a}}$ \\ University of South Carolina \\ and \\ Gaiyan Zhang \\ University of Missouri - St. Louis
}

May 28, 2013

JEL Classification: G21, G24, G28, G32, G33, E44, E58, E61

Keywords: Banks, counterparty contagion, information contagion, bankruptcy

We thank Giovanni Bassani, Ryan Benitez, Brian Betker, Régis Blazy, Art Boman, Nicole

Boyson, Kelly Cai, Moorad Choudhry, Pierre Collin-Dufresne, Lee Crabbe, Sergei Davydenko, Shingo Goto, Robin Grieves, Jay Huang, Hung-gay Fung, Peter Iliev, Kevin James, Jan Jindra, Stephen Lubben, Chris Muscarella, Matt Pritsker, Marianne Schulze-Ghattas, Larry Wall, Gang Xiao, DH Zhang, and seminar participants at Auckland University of Technology, University of Canterbury, Humboldt University, London School of Economics, North Carolina State University, Northeastern University, the Office of Financial Research, Penn State University, St. Louis University and University of South Carolina for helpful comments. Ruixue Geng, Raluca Roman and Liyang Wang provided excellent research assistance.

${ }^{a}$ Corresponding author is Helwege: email - jean.helwege@moore.sc.edu. Phone - (803) 7774926

Zhang: email - zhangga@umsl.edu. Phone-(314)5166269. 


\title{
Financial Firm Bankruptcy and Contagion
}

\begin{abstract}
The Lehman bankruptcy highlights the potential for interconnectedness to cause negative externalities through counterparty contagion, but the externalities may also arise from information contagion. We examine contagion from troubled financial firms and find that counterparty contagion is greater during recessions and in cases of riskier firms and larger and more complex exposures. However, the counterparty exposures are small, especially among banks that face diversification regulations, and do not typically cause a cascade of failures. Information contagion is stronger for rivals in the same locale or the same line of business and is stronger in cases of distress than in bankruptcies.
\end{abstract}


When companies file for bankruptcy other firms in the same industry often suffer as a result. Lang and Stulz (1992) conclude that rivals' stocks drop in response to the news because investors learn about future industry cash flows from the filing. Consistent with their work, Jorion and Zhang (2007) report that credit default swap (CDS) premiums typically rise for firms in the same industry after a default. Theocharides (2008) and Hertzel and Officer (2012) show evidence of similar patterns for corporate bonds and bank loans, respectively. ${ }^{1}$

While these studies show a significant industry impact from corporate bankruptcy, the nature of the contagion is not well understood. The effects on other firms may owe to information flows, which arise when the bankruptcy causes investors to update their beliefs about firms that share similar characteristics of the failed firm (information contagion). ${ }^{2}$ However, the effects may also reflect counterparty contagion which occurs when a distressed firm imposes losses on its creditors (Jorion and Zhang, 2009), or when a distressed firm withdraws funding from its borrowers (Ivashina and Scharfstein, 2010). ${ }^{3}$ Losses for counterparties seem more probable in cases of financial firms, which are more likely to do business with other firms in the industry. Since the subprime crisis, many researchers have emphasized interbank relationships and their potential for generating contagion. For example, Acharya, Brownlees, Engle, Farazmand, and Richardson (2010) assert that "interconnections...in a crisis may transfer risk and losses across financial firms, resulting in cascading failures.”

\footnotetext{
${ }^{1}$ Rivals' securities prices may actually improve with the bankruptcy announcement if the event suggests lower capacity for the industry and thus higher profits. Such positive returns are uncommon, but Zhang (2010) finds significant competitive effects when firms exit bankruptcy.

${ }^{2}$ See Lang and Stulz (1992), Benzoni, Collin-Dufresne, Goldstein and Helwege (2012), and Veronesi (2000).

${ }^{3}$ We use the term contagion to focus on causality, as opposed to firm correlations that may not involve a causal link. Counterparty contagion arises from various kinds of bilateral transactions, which is different from other forms of contagion that occur in intermediated markets (see Staum (2012)).
} 
Rochet (2010) declares that the "complex nexus of OTC transactions" in interbank markets generates negative externalities, so that one firm's troubles may cause others. However, the degree of bank interconnectedness, the severity of interbank contagion via counterparties, and its impact on systemic risk in the U.S. financial system require more quantitative research.

The policy implications of financial firm failures vary sharply with the nature of the contagion. As Helwege (2010) notes, if counterparty contagion dominates then aid to business partners and clients of the bankrupt financial firm will be the most effective way to mitigate the impact of a shock. In contrast, if information contagion is a larger source of valuation effects, then government policy should focus on strategies that apply to a wide swath of the economy rather than to a small set of firms with direct exposures to the failing firm. ${ }^{4}$

In this paper we investigate whether counterparty contagion and information contagion are significant sources of contagion from troubled financial firms over the period 1980-2010. We evaluate counterparty contagion by considering the breadth and magnitude of counterparty exposures, as well as the impact of bankruptcies on equity returns and the frequency of cascades of distress. We identify counterparties from bankruptcy court filings (see Jorion and Zhang (2009)) and from sources related to the failures of Lehman Brothers and American International Group (AIG). To examine whether information contagion is also a significant source of contagion after controlling for counterparty effects, we extend the approach of Lang and Stulz (1992) to firms in the same industry that operate in the same locale or that have similar assets while excluding rivals that are also creditors of the failed firms.

\footnotetext{
${ }^{4}$ Allen, Babus and Carletti (2009) conclude that “The developments after Lehman....in September 2008 suggest that contagion is indeed a serious problem. However, contagion did not manifest itself as a wave of failures suggesting a more complex phenomenon that is currently not well understood. A full understanding of contagion is necessary before adequate policy responses can be designed.”
} 
Overall, our study provides quantitative evidence that contagion among financial firms reflects the similarity of financial firms' business models as much as interbank lending. Both counterparty contagion and information contagion have significant effects on other firms' stock prices. Counterparty contagion effects are larger for firms with greater exposures and exposures involving derivatives, for firms with higher equity return volatilities, and during recessions. Nonetheless, counterparty contagion effects are modest for most financial firm bankruptcies, especially for commercial banks, which likely reflect the fact that many financial firms are required to hold diversified portfolios. Furthermore, counterparty contagion does not typically cause a cascade of failures. Information contagion effects are stronger for rivals in the same locale or the same line of business and are stronger in cases of distress than in bankruptcies.

We show that counterparty risk is limited because exposures of other financial firms are fairly small, which reflect regulations about diversification and the fact that undiversified risk is not rewarded by the market. We find a higher degree of interconnectedness for Lehman and AIG, but most of their creditors had exposures that were no more than ten percent of their equity. These results support Scott (2012), who argues that interconnectedness was not the primary driver of systemic risk in the recent financial crisis.

Contrary to prior studies of information contagion, such as Lang and Stulz (1992), we do not find significant valuation effects on stocks in the same industry. However, we do find information contagion when we examine firms in the same locale or the same line of business, consistent with studies indicating that geographic proximity and similarity of assets are significant determinants of other banks' revaluations (Aharony and Swary (1996), Karafiath and Glascock (1989) and Dickinson, Peterson, and Christiansen (1991)). ${ }^{5}$ These effects persist after controlling for equity correlations between distressed firms and their rivals. We find stronger

\footnotetext{
${ }^{5}$ Pirinsky and Wang (2006) show strong comovements in the stock returns of firms headquartered in the same geographic area.
} 
results for cases of distress, suggesting that information contagion is significant among firms that are considered "too big to fail” (TBTF).

Ours is the first study to examine counterparty contagion and information contagion with a large sample of financial firm bankruptcies and distresses. While counterparty contagion theory highlights the damage that interconnectedness might cause in a financial system collapse, empirical evidence that speaks to this channel is limited. One challenge in testing counterparty contagion is to identify the counterparty relationship and the magnitude of the exposure. Our study is able to overcome this hurdle with detailed information about counterparty and actual exposure amounts. Our paper is closely related to Jorion and Zhang (2009) and Hertzel, Li, Officer and Rodgers (2008) who examine ties between bankrupt firms and their creditors and suppliers. While each finds significant negative valuation effects, most of their sample firms are in the nonfinancial sector and their sample periods end before the recent financial crisis. Other related papers include Ivashina and Scharfstein (2010), who examine linkages between banks and their borrowers, and Furfine (2003), who uses data on interbank fund flows to simulate the impact of various failure scenarios. In addition, several studies of counterparty contagion in the wake of the financial crisis are based on a single large bankruptcy, such as that of Lehman (Aragon and Strahan (2012), Chakrabarty and Zhang (2012), Fernando, May and Megginson (2012), and Jorion and Zhang (2012)) or a large bank in India (Iyer and Peydró (2011)).

Information contagion from financial firm failures is examined by Aharony and Swary (1983, 1996), Fenn and Cole (1994), Fields, Ross, Ghosh, and Johnson (1994), Fields, Klein, and Myskowski (1998), Jorion and Zhang (2012) and Chakrabarty and Zhang (2012). However, few of these authors consider counterparty risk and most examine a small sample of distressed financial firms. Furthermore, most information contagion studies investigate spillover effects at 
the industry level, whereas we conduct a finer analysis to test information contagion on industry rival firms that share similar characteristics as distressed firms.

Our study contributes to a large literature on financial contagion channels including recent papers on fire sales ((e.g, Allen, Babus, and Carletti (2011), Brunnermeier (2009), Shleifer and Vishny (2011), and Wagner (2011)) and market liquidity (e.g., Boyson, Stahel and Stulz (2010), Brunnermeier and Pedersen (2009), Covitz, Liang, and Suarez (2012), Dudleya and Nimalendrana (2011), Gorton and Metrick (2012), Kacperczyk and Schnabl (2010), Longstaff (2010), Mitchell and Pulvino (2012), and Strahan and Tanyeri (2013)). Fire sales might explain why we find stronger information contagion effects for firms operating in the same business, as they are likely to hold similar assets and would suffer greater losses from fire sales. Similarly, industry information contagion effects may reflect liquidity problems among firms that rely on the same markets for funding. We note that most of these studies rely on aggregate data whereas our study is based on micro-level risk at the firm level.

In the next section we review related studies and present testable hypotheses. Section 2 summarizes our data and provides details on the event study methodology; Section 3 presents empirical results and robustness tests; and Section 4 concludes.

\section{Analytical Framework}

Federal Reserve Chairman Ben Bernanke summarized the logic of counterparty contagion theories well in his March 2009 television interview on CBS:

Interviewer: "Mr. Chairman, there are so many people...who say, 'To hell with them. They made bad bets. The wages of failure on Wall Street should be failure.'” 
Bernanke: "Let me give you an analogy. If you have a neighbor who smokes in bed...If suppose he sets fire to his house, and you might say to yourself, you know 'I'm not going to call the fire department. Let his house burn down. It's fine with me.' But then of course,... what if your house is made of wood? And it's right next door to his house? What if the whole town is made of wood?... What needs to be done to make sure this doesn't happen in the future? How can we fireproof our houses? That's where we are now. We have a fire going on."

Bernanke's analogy aligns well with models of the interbank lending market posited by Rochet and Tirole (1996), Allen and Gale (2000), and Eisenberg and Noe (2010), as well as with the corporate bond pricing models of Jarrow and Yu (2001), Davis and Lo (2001), Giesecke and Weber (2004), and Kraft and Steffensen (2007)). Counterparty risk is also an important element of derivatives pricing (e.g., Cooper and Mello (1991)). More recently, counterparty contagion theory research has focused on exchanges and clearinghouses as methods for mitigating this source of systemic risk (Duffie and Zhu (2012) and Pirrong (2009)).

Hertzel, Li, Officer and Rodgers (2008) and Jorion and Zhang (2009) examine the impact of bankruptcies on counterparties, but both studies focus on bankrupt nonfinancial firms and periods before the subprime crisis. Thus, their results may understate the extent of contagion arising from financial firms in financial crises. Studies that examine Lehman's collapse and firms with which it had direct business ties find a significant negative impact (Ivashina and Scharfstein (2010), Aragon and Strahan (2012), Fernando, May and Megginson (2012), Jorion and Zhang (2012), and Chakrabarty and Zhang (2012)). Using data from the subprime crisis, Arora, Gandhi and Longstaff (2012) examine counterparty risk in CDS contracts while Iyer and Peydró (2011) provide evidence of counterparty contagion from a large bank failure in India. A number of 
systemic risk measurement studies show strong correlations between financial firms' equities, consistent with the existence of interconnectedness in capital markets. ${ }^{6}$ In sum, previous research suggests that exposure to a bankrupt financial firm may be a significant source of contagion.

We examine counterparty contagion in cases of financial firm bankruptcies by investigating the absolute and relative size of counterparty exposures and stock returns of firms with direct business ties to the bankrupt company. If this is a significant element of financial firm bankruptcies, creditors in a bankruptcy filing would be affected the most and those with the most negative valuation effects would be the ones with the largest unsecured claims. In contrast, firms with small debts or debts with low losses (collateralized debt) would not be affected as much: ${ }^{7}$

H1: Financial firm bankruptcies have negative effects on other financial firms that are creditors and the magnitude of the effects is greatest among the unsecured creditors with the largest claims.

Interconnectedness among financial firms is likely to be strongest at larger banks that have substantial dealings in capital markets (Adrian and Brunnermeier (2010)). Such firms have larger portfolios, more diverse product lines and are more likely to enter into bilateral contracts (such as CDS and other derivatives) that directly impact the probability of failure of another firm (Giglio (2011)). In contrast, community banks that fail may have a small impact because the losses involved are smaller and because they fund their assets with retail deposits rather than global

\footnotetext{
${ }^{6}$ See Acharya, Pedersen, Phillipon and Richardson (2010), Adrian and Brunnemeier (2010), Billio, Getmansky, Lo and Pelizzon (2012), Drehmann and Tarashev (2011), Huang, Zhang and Zhou (2009), Suh (2011), and Yang and Zhou (2012). Das, Duffie, Kapadia and Saita (2007), Duffie, Eckner, Horel and Saita (2009) and Lando and Nielsen (2010) consider clusters of defaults that may represent systemic risk.

${ }^{7}$ If collateral backing a secured debt or derivative is not sufficient for a secured creditor to recoup his entire claim, the impaired part of the claim is included in the bankruptcy document as an unsecured creditor claim. Thus, by definition, the unsecured creditor claims are more likely than collateralized debt to involve losses to related firms.
} 
capital markets. Thus, an alternative formulation of $\mathrm{H} 1$ focuses on the effects of bankruptcy filings by large firms:

H1a: Large financial firm bankruptcies have negative effects on other financial firms that are creditors and the magnitude of the effects is greatest among the unsecured creditors with the largest claims and those related to derivatives.

We could amend $\mathrm{H} 1$ and $\mathrm{H} 1 \mathrm{a}$ to include cases of financial distress, as these troubled firms would also impose costs on their creditors and the effects would also be greatest among the distressed firms' unsecured creditors. Specifically, creditors of distressed firms that have not yet entered Chapter 11 will correctly forecast greater expected losses on their loans to these nearly insolvent firms. However, the costs to counterparties should be smaller ceteris paribus than those arising from Chapter 11 firms because the distressed firm might avoid default and pay its creditors in full before the debt maturity date. ${ }^{8}$ Nonetheless, if the claims are large enough and the failure is sudden, counterparty contagion could well apply to distressed firms as well as bankrupt firms:

H1b: Distressed firms have negative effects on other financial firms that are creditors and the magnitude of the effects is greatest among the unsecured creditors with the largest claims. The most extreme negative effect on a counterparty occurs when a bankruptcy filing causes losses that drive a creditor into bankruptcy, which in turn could cause a third bankruptcy. The Economic Report of the President (2010) states that "Some crises ... are triggered or exacerbated by shocks to a small group of institutions that then spread to others. This spread, known as contagion, is a form of negative externality imposed by distressed institutions. The recent

\footnotetext{
${ }^{8}$ For example, a hedge fund that hears about the distress of its prime broker could move its business elsewhere before the firm actually files for bankruptcy. Or, if the claim is a short-term debt contract such as an overnight repo or commercial paper, the creditor may no longer be involved with the debtor firm when it files for bankruptcy protection.
} 
financial crisis involved ...counterparty contagion.......[as] illustrated in Figure 6-5.... Bank A owes $\$ 1$ billion to Bank B, which owes $\$ 1$ billion to Bank C, with this same debt going through the alphabet to Bank E. When Bank A goes out of business owing money to Bank B, then Bank B cannot pay Bank C....One failure could lead to defaults all the way to Bank E.” Such logic spurred the provision in Dodd-Frank requiring central clearing parties for derivatives trades (Cecchetti, Gyntelberg and Hollanders (2009), Hull (2010), Pirrong (2011) and Duffie and Zhu (2011)). Thus, we consider the frequency of subsequent bankruptcies in hypothesis H2:

H2: Financial firm bankruptcies cause other financial firms that are creditors to file for bankruptcy, leading to a cascade of failures.

In contrast to counterparty contagion, Lang and Stulz (1992) consider information contagion. Several theoretical papers consider how bankruptcy or distress might lead to losses on stocks or bonds of other firms as investors incorporate the news about common factors into securities prices (e.g., Veronesi (2000), Benzoni, Collin-Dufresne, Goldstein and Helwege (2012), Giesecke (2004), King and Wadhani (1990), and Kodres and Pritsker (2002)). ${ }^{9}$

If information effects are an important factor in financial firm failures, then bankruptcy filings will contain the most negative news for stocks of firms with similar businesses or subject to the same common factors (Flannery (1998)). Aharony and Swary (1996) indicate that geographic proximity to a failed firm is a significant determinant of other banks' revaluations. ${ }^{10}$ The failures of First Republic Bank and Penn Square, studied by Karafiath and Glascock (1989)

\footnotetext{
${ }^{9}$ Bai, Collin-Dufresne, Goldstein and Helwege (2012) consider a model of corporate bond pricing where contagion could represent information effects or counterparty risk.

${ }^{10}$ Geographic proximity is especially important for depository institutions as they were restricted from operating across state lines until 1994. While our proxy for geographic proximity (located in the same state) is a relatively coarse measure, it is sufficient to find significant information contagion effects.
} 
and Dickinson, Peterson, and Christiansen (1991), respectively, highlight the similarity of competitors' loan portfolios in understanding the externalities. However, most existing studies on information contagion fail to control for counterparty effects. Exceptions are Jorion and Zhang (2012) and Chakrabarty and Zhang (2012), who analyze Lehman’s bankruptcy. To separate out information effects from counterparty effects, we exclude rival firms that are also creditors of the event firms. Our third hypothesis is formulated as follows:

H3: Bankrupt and distressed financial firms have negative effects on other financial firms and the magnitude of the effects is greatest among industry peers (firms in the same 4-digit SIC code) that are in the same line of business or are located in the same state.

Note that H3 applies to distressed firms as well as bankrupt firms. We consider distressed firms as well as bankrupt ones because the information that triggers losses on related firms' stocks may appear well before the bankruptcy date. Further, distressed firms' news may impact competitors even if their troubles never result in a bankruptcy filing.

The relationship between size and information is not clear: While large firms' failures may impact all firms with related assets, simply because failures of large firms induce more reporting, small firm bankruptcies may be more relevant for other small firms in the same geographic locale because they have similar investments and funding sources.

Our focus is on negative externalities, but competitive effects could result in positive stock returns for rivals (Slovin, Shushka and Polonchek (1999) and Egginton, Hilliard, Leibenberg and Leibenberg (2010)). If competitive effects cause positive reactions, this should occur more often among firms that operate in the same product markets. 
H4: Bankrupt and distressed financial firms have positive effects on other financial firms and the magnitude of the effects is greatest among industry peers (same 4-digit SIC code) that are in the same line of business or are located in the same state.

\section{Data and Methodology}

Our analysis requires data on two types of firms: (1) troubled firms whose bankruptcy filings or news of distress might generate negative externalities and (2) other firms that might suffer from contagious episodes (counterparties and rivals). We examine the market reactions of affected firms by applying standard event study methodologies.

We create equally weighted portfolios of creditors and of peer firms, where the latter include firms in the same 4-digit SIC code that are not also creditors of the troubled firm. ${ }^{11}$ The abnormal return $\left(A R_{j t}\right)$ for portfolio $\mathrm{j}$ on day $\mathrm{t}$ is defined as follows:

$$
A R_{j t}=R_{j t}-\left(\alpha_{j}+\beta_{j} R_{m t}\right)
$$

where $R_{j t}$ is the rate of return for portfolio j on day t. The market model parameters $\left(\alpha_{j}, \beta_{j}\right)$ are estimated using the CRSP value-weighted index as the market return $\left(R_{m t}\right)$. The CRSP return is over a 200-trading-day window that ends 50 days before the event. We average these abnormal returns over the event window $\left[T_{1}, T_{2}\right]$, where $T_{1}$ and $T_{2}$ are the number of days relative to the day of the bankruptcy announcement or the distress day. We follow MacKinley (1997) in measuring statistical significance and we also report the proportion of negative abnormal returns among individual stocks.

a. Bankruptcy filings

\footnotetext{
${ }^{11}$ We construct equally-weighted portfolios, but we find similar (unreported) results with value-weighted portfolios.
} 
We obtain our sample of 142 financial firm bankruptcies from www.bankruptcydata.com, which we match to firms in CRSP and Compustat with SIC codes in the 6000 range in the period 1980-2010. This is also our source for data on creditors, which usually includes the names and exposures of the top 20 unsecured claimants. The creditor data are available only for 88 of the 142 bankrupt firms because that information is largely available only after 1999. We obtain stock return data for these counterparties by matching their names to those on CRSP.

\section{b. Distressed firms}

Using the procedure in Gilson (1989), we examine 3-year cumulative stock returns and select the stocks of financial firms that are in the bottom 5\% of the CRSP universe during the years 1980-2010. We further limit the sample to firms that have assets above the sample median in order to concentrate on episodes of distress that are important. Following Hertzel, Li, Officer and Rodgers (2008), the distressed event date is the day when the firm's stock price experiences the largest decline in the 3-year period window. ${ }^{12}$ We investigate the news in Lexis-Nexis to confirm that each distress day decline occurs as a result of new information about the firm. If we find no news to explain the decline, we eliminate the observation. We also require that two consecutive events involving firms in the same 4-digit SIC industry code be at least two weeks apart in order to isolate the effects of information contagion. The distressed firms sample includes 149 financial institutions. Their worst daily stock returns range from $-6.5 \%$ to $-90 \%{ }^{13}$

\footnotetext{
${ }^{12}$ We also consider distressed firms' quarterly earnings announcements by examining days with negative earnings surprises that lead to negative returns. In unreported estimations, we find that these dates often indicate distress earlier than the distress days in our analysis, but the effects of contagion are quite weak on such negative earnings days.

${ }^{13}$ The distressed firms sample and the bankrupt firms sample are not mutually exclusive, so 36 of the 149 firms in the distressed sample are also in the bankruptcy sample (the remaining firms are mostly excluded by the size restriction). In untabulated results, we find that excluding the bankrupt firms from the distress sample does not qualitatively change our findings.
} 


\section{c. Rivals}

We identify firms that may suffer from information contagion using Compustat's 4-digit industry codes. ${ }^{14}$ Rival firms must also have stock return data on CRSP in order to construct portfolios. We exclude rival firms that are also creditors of troubled financial firms to separate out information contagion from counterparty effects. Information from a bankruptcy or distress event will be most relevant for firms that are operating in the same geographic area as the troubled firm (Aharony and Swary (1996)), so we further narrow down the set of relevant peer firms by also including data on locations from Compustat. A large number of bankrupt and distressed financial firms get into trouble as a result of investments in real estate (Cole and White (2012)), which cuts across 4-digit SIC industries. Thus, we also create portfolios of firms in the real estate (RE) business by investigating the companies' business lines in Lexis-Nexis. If the news explicitly mentions that the troubled firm experienced distress due to real estate investments, we set the RE variable to one. For rival firms, we create the RE indicator using the following method: First, we read the descriptions of SIC codes (all the firms in SIC codes 6162, 65xx, and 6798 are in real estate). For other industries, we read Compustat business descriptions. If terms such as 'real estate', 'mortgage', or 'properties' are mentioned in the blurb, the RE variable is set to one. When the business descriptions in Compustat are abbreviated and incomplete, we also read descriptions in Businessweek (which start with the same words as those in Compustat, but are more detailed). ${ }^{15}$ If a firm in a non-RE SIC code industry does not have a business description in either Compustat or Businessweek, its RE indicator value is missing.

\section{d. Summary statistics}

\footnotetext{
${ }^{14}$ Kahle and Walkling (1996) show that SIC codes frequently differ between CRSP and Compustat.

${ }^{15}$ See http://investing.businessweek.com/research/common/symbollookup/symbollookup.asp
} 
Table I presents summary statistics on the bankrupt firms and distressed firms samples. Panel A shows the time series of bankruptcy filings and worst days for the distressed firms. Not surprisingly, the worst year in our sample is 2009, when 25 publicly traded financial firms declared bankruptcy. Panel B shows the industries of these financial institutions. The largest industry among the 4-digit SIC codes is commercial banking, whether we look at bankruptcies or distress. These firms, along with other depository institutions, make SIC code 60 the largest of the 2-digit categories. Several dozen insurers (SIC 63) are in both the bankrupt firms and distressed firms samples, but life insurers tend to avoid bankruptcy to a greater extent than property and casualty insurers. Mortgage brokers and real estate investment trusts (REITs) are also common among the bankrupt firms, but only the REITs also have large numbers in the sample of distressed firms. Panel C shows that the bankruptcies and cases of distress are more often located in the most populous states. California, New York, Texas, Florida, Illinois, Pennsylvania, North Carolina and Georgia are among the 15 largest states by population and they contribute $68.3 \%$ and $48.3 \%$ of the observations to the bankruptcy and distressed firm samples, respectively. Notably absent from the list are New Jersey and Michigan, which contribute only a few observations to the samples despite their large population. Panel D confirms the findings of Cole and White (2012) that many bankrupt and distressed financial firms are exposed to declines in real estate values. Nearly two-thirds of the bankrupt firms are in the real estate business.

Among the various reasons for investigating distressed firms separately from bankrupt firms is the fact that some financial institutions were considered by regulators to be TBTF during our sample period. Thus, the average bankrupt financial firm measured by assets could be much smaller than the TBTF firm. By including distressed firms we are able to investigate the effects 
of some of the TBTF companies (although if market participants are certain that the stock will be treated favorably in a TBTF rescue, the equity may not fall sufficiently to be included in our distressed firm sample either). Panel E shows that the distressed firms are indeed larger than the bankrupt firms, even though Lehman ( $\$ 691$ b. in assets) is part of the bankrupt firms sample. Our largest distressed firm is Royal Bank of Scotland, which ran into trouble during the subprime crisis as a result of losses on mortgage-related assets. Other large distressed firms include Citigroup, Fannie Mae, Freddie Mac, and Bear Stearns.

Table II shows data on the number of firms in the rival firm portfolios and the number of creditors. There are fewer bankrupt and troubled firms with rivals that are located in the same state, and some of the ones that do only have a few observations in the portfolios of affected firms. The bankrupt and distressed firms in RE are much more likely to have a number of rivals that are also in RE. Table II also shows the number of firms in our sample that are likely to be affected by counterparty contagion in a bankruptcy. These creditors often do not have publicly traded equity, which is necessary for an event study of the effect of counterparty contagion. The main reason why creditors are not publicly traded is that they are trustees and thus do not themselves bear the costs of counterparty risk.

Trustees are typically among the largest unsecured creditors of a bankrupt firm (Jorion and Zhang (2009) and Helwege (2010)). For example, in the case of Washington Mutual (WAMU), which went bankrupt in September 2008, the largest unsecured creditor is the Bank of New York (BONY) as trustee for the junior subordinated debentures. These bondholders as a group are 
owed $\$ 1.15$ billion and BONY is responsible for filing the claim against WAMU, but BONY is not owed \$1.15 billion and BONY does not negotiate a recovery rate on the bond. ${ }^{16}$

While these claims are large, each of the bonds is owned by bondholders such as pension funds, insurance companies, mutual funds and hedge funds. Evidence from Emaxx data reported by Han and Zhou (2009) indicates that bonds are typically held by 103 institutional investors. These data are based on large institutional investor reports to the SEC and insurance regulators, so they provide a lower bound on the number of bondholders. Massa, Yasuda and Zhang (2010) show that the investors in the Emaxx database hold approximately half of the par amount outstanding of the bonds. Applying these figures to the largest bond claim owed by WAMU of $\$ 1.15$ billion, the typical bondholder exposure is estimated to be $\$ 5$ to $\$ 10$ million. Thus, even if the ultimate creditors were reported instead of the trustees, the claims would likely be too small to make the list of the top 20 creditors. ${ }^{17}$ In the sample of 88 firms with creditor information, nearly all have at least one unsecured creditor that is not a trustee.

Table II shows that the many of the creditors that are not trustees are financial firms, as one would expect if interconnectedness is a major element of a financial crisis. Indeed, the vast majority (79 of 88) has at least one financial firm creditor at the time of the bankruptcy filing. In results not shown, we find that this measure of interconnectedness is high for both commercial banks and other financial firms. However, Jorion and Zhang (2009) and Helwege (2010) note that commercial banks are unlikely to be the top unsecured creditors because bank regulations on

\footnotetext{
${ }^{16}$ In fact, the next 12 largest unsecured creditors of WAMU are all BONY as trustee for some group of bondholders, with claims ranging from \$176 million to \$805 million.

${ }^{17}$ This aspect of our study is not peculiar to financial firm bankruptcies, as Jorion and Zhang (2009) report similar patterns for their sample. Of 370 bankrupt firms that have investors in debt securities among their 20 largest unsecured creditors, only 270 have such creditors that are not trustees.
} 
the size of loans to one borrower limit their exposures. As an example, the largest unsecured WAMU creditor after the trustees is Verizon with a claim of about $\$ 7$ million (presumably for unpaid telephone bills). However, some bankruptcies, such as Lehman's, have banks among the top 20 creditors and these may be at the heart of financial crises.

A concern with the creditors in Table II is that the samples are small and thus that other important counterparties are overlooked in our analysis. We address this issue in two ways. First, we note that the smallest of the top 20 creditors often has a claim that is less than $\$ 20$ million, which means the omitted creditor claims would be too small to trigger a second bankruptcy and therefore are not very interesting. Second, in the robustness tests section we also investigate the exposures of counterparties of Lehman and American Home Mortgage (AHM) using data from an alternative source, Epiq Systems debtorMatrix. The Epiq data include all the creditors of these two firms. ${ }^{18}$ This concern is also mitigated somewhat by the data on counterparties of AIG, which include all the creditor firms that regulators perceived as capable of causing disruptions in capital markets. Data for AIG are also discussed as part of our robustness checks.

Lehman is the largest bankruptcy in the history of the United States, with nearly $\$ 700$ billion in assets at the time of its Chapter 11 filing. While Lehman was not considered TBTF by regulators on September 15, 2008, many people say that it should have been. Indeed, Chairman Bernanke stated in the above-quoted interview that he wished the government could have rescued Lehman. A second large firm in our study, AIG, was undoubtedly a TBTF firm when it became distressed in fall 2008. We know this because of its $\$ 85$ billion emergency loan a few days after Lehman collapsed. The loan was subsequently reworked and increased to ensure that

\footnotetext{
${ }^{18}$ The source for Lehman is http://chapter11.epiqsystems.com/LBH/claim/SearchClaims.aspx?rc=1, which is the same as in Jorion and Zhang (2012). We use data on Lehman creditors from both sources (Epiq and www.bankruptcydata.com), whereas AHM data are only in Epiq.
} 
AIG was not forced into bankruptcy. Indeed, because its bailout was so large and famous, AIG's major creditors were the subject of Congressional testimony, which is the source of our data. The testimony about AIG reveals 51 claims owed to 29 firms, including 19 publicly traded financial firms with data on Compustat and CRSP (most of the rest are foreign banks).

\section{Results}

We present the results of three types of test in this section. To test $\mathrm{H} 1$ and $\mathrm{H} 2$, we analyze the absolute and relative size of unsecured creditor claims and therefore the potential size of exposures that could cause counterparty contagion. Another metric for the size of the exposure is the number of creditors that subsequently file for bankruptcy as a result of large exposures. Second, we conduct event studies on the bankruptcy announcements to determine if the impact on creditors is greater than that on other firms in the financial sector. Lastly, we carry out event studies on the effects of distress and bankruptcy on rival firms to determine the extent to which contagion is information-based, as predicted by $\mathrm{H} 3$ and $\mathrm{H} 4$.

\section{a. Counterparty contagion and the size of creditor exposures}

In Table III we investigate the size of the claims owed by the sample of 88 firms with data on creditor claims. Panel A shows the aggregate value of the claims and the overall distribution of the debt. These firms owed more than $\$ 250$ billion to their unsecured creditors, with the average owed per bankruptcy reaching nearly $\$ 3$ billion. However, most of the bankrupt firms are small, so that the median amount owed to the top unsecured creditors is only \$77.6 million. Further, the money is mostly owed to trustees, not to other financial firms. Nearly half of the 88 bankruptcies have at least one creditor that is a trustee and these trustees are owed $\$ 226.6$ billion, or almost $90 \%$ of the aggregate owed to unsecured creditors. Once we eliminate the trustee 
creditors, the amounts owed drop precipitously. So, even though nearly every bankrupt firm in our sample has a financial firm as a creditor, which is consistent with the view of widespread interconnectedness in capital markets, creditors that are also financial firms are only owed \$27 billion in total, or only $\$ 344$ million per bankruptcy on average.

Panel B of Table III shows data for the creditors that are financial firms. The mean amount owed to these creditors is only $\$ 53.4$ million and the median is sharply lower at less than $\$ 4$ million. While these low figures may reflect the effect of TBTF policy, driving down the average firm size among the 88 firms, we note that the Table III data include claims against Lehman and WAMU, the two largest U.S. bankruptcies to date. Yet no claim of another financial institution is as high as $\$ 2$ billion and only 4 percent of the claims are above $\$ 1$ billion. The largest single claim is for $\$ 1.9875$ billion owed by CIT, which filed for Ch. 11 protection in November 2009. Note that the largest amount owed in the case of a bankrupt commercial bank is only $\$ 79.1$ million. Thus, the potential for a cascade of bankruptcies among interconnected financial firm creditors is smaller than that for creditors overall.

In order to gauge how large these exposures are relative to a creditor's ability to absorb losses, we require data on the size of the balance sheet of the creditor, which is only available for the creditors that are publicly traded. We report the summary statistics related to their claims in Panel C of Table III. Note that the publicly traded firms are generally larger than private firms, so the creditors in Panel C are more likely to cause a financial panic. Despite their large size, their average and median unsecured claims are smaller than in the total sample. And in cases of bankrupt commercial banks, the claims are typically smaller still.

Compared to the overall assets of the publicly traded creditors, the claims owed to them by bankrupt financial firms are very small. Panel D shows that these claims are only .05\% of their 
total assets on average. This is consistent with the conjecture in Helwege (2010) that financial firm exposures are limited because regulations require diversification. In particular, bank regulations require that loans to one borrower be no more than 15 percent of the capital of the bank. Since few banks have capital that exceeds $10 \%$ of their assets, this effectively means that most loans will be below $1.5 \%$ of assets. Likewise, insurance company regulations require portfolios be diversified and the SEC constrains mutual funds as well.

Moreover, financial firms do not often extend credit that is uncollateralized. For example, many bank loans are secured, repurchase agreements (repos) involve securities for borrowing, and most derivative contracts are collateralized. Thus, some of the unsecured claims in a bankruptcy will relate only to the portion of a secured loan that has insufficient collateral behind it. Consequently, the average unsecured claim of a bank that is a creditor in a bankruptcy should be well under $1.5 \%$ of assets if most financial firms observe rules related to diversification.

While the average and median exposures are quite small as a percentage of assets for publicly traded creditors as a whole, Panel D shows that the figures are even smaller for commercial banks than other creditors (mean of .03 versus .06). This reflects the fact that some of the other publicly traded creditors are (unregulated) nonfinancial firms. We test whether commercial creditors have exposures that are more than $1.5 \%$ of assets, which would indicate that diversification regulations are not enforced. We find in Panel D that unsecured claims are always less than $1.5 \%$ of the assets of the bank. Indeed this is true for all creditor firms in Panel $\mathrm{D}$, even when the creditor is not a regulated financial institution.

Although the creditors have small exposures when measured against their entire portfolios, most financial institutions are highly levered firms. Thus the losses from financial firm bankruptcies could be quite high as a fraction of the creditor's equity. Panel E shows that 
creditors stand to lose an average of about $.25 \%$ of the market value of their equity as a result of exposures to bankrupt firms, which is again consistent with a policy of diversifying risk. Nonetheless, in some cases the losses are substantial - in one case as high as $12 \%$ of the firm's equity. ${ }^{19}$ While a loss of ten percent or more of the equity of a publicly traded company would be an extreme event in the stock market, we note that none of the firms in the sample appear to have large enough exposures to drive them to insolvency when another financial firm fails.

It may be that one single bankruptcy is not sufficient to cause a second failure, but that financial institutions are interconnected in such a way that several failures would cause them to collapse. We consider this mechanism by aggregating the claims of each creditor across all the bankruptcies in the sample. Panel F shows that the aggregate claims for each creditor in our database average about $\$ 84$ million, which is only about twice that of the average amount per creditor shown in the upper rows of the table ( $\$ 53.4$ for financial institutions and $\$ 46.3$ for publicly traded creditors). Thus, the creditors usually are not involved in more than two bankruptcies during the sample period. The firm with the most claims in the dataset (four) is Goldman Sachs, they only amounted to only $5.53 \%$ of its market value. ${ }^{20}$

The data in Panels A - F of Table III suggest that none of the exposures to the bankrupt firms are large enough to wipe out the equity of the counterparties, even if all of the exposures for a particular creditor are aggregated together. However, these bankrupt firms might be

\footnotetext{
${ }^{19}$ Note that the bankruptcy of a commercial bank involves exposures that are very small, but when a commercial bank is a creditor its losses are a higher fraction of its equity. This asymmetry in the risks suggests that the high leverage of commercial banks is a larger factor than a greater degree of interconnectedness.

${ }^{20}$ This doesn’t include Goldman Sachs' exposure to Lehman, which is obtained from Epiq and may be overstated as described below.
} 
considered too small to cause systemic risk, as each one was allowed to fail. We consider the exposures of larger firms such as Lehman and AIG later as a robustness check.

Another test of the potential for a cascade of failures from counterparty risk calculates the number of firms that enter distress after suffering losses as creditors. We do this for the 90 firms with data on creditors (the 88 bankruptcies in Table III, AHM and AIG) and their 287 publicly traded creditors. Using CRSP delisting codes, bankruptcydata.com, and Lexis-Nexis, we find that 10 of these creditor firms subsequently file for Chapter 11 protection, two file for Chapter 7 liquidation, another files for bankruptcy in Canada, two are acquired in distress (so they might have gone bankrupt given more time as independent firms), and six more are among our list of distressed firms. However, it is not clear that the any of these companies fell into distress as a result of the first bankruptcy. Of the creditors that subsequently faced their own troubles, six were suffered losses from AHM, but all were owed sums that were a small fraction of their assets. It is unlikely that these creditors, including Lehman, Countrywide, WAMU, Bear Stearns and MBIA, all failed as a result of AHM. Thus, these bankruptcies are not well described as part of a domino-like chain reaction.

\section{b. Counterparty contagion and stock market returns of creditors}

Our second approach to evaluating the potential impact of counterparty contagion from financial firm bankruptcies is an event study of the creditors' stock returns on the bankruptcy date. Table IV, Panel A shows that creditors suffer significant losses as a result of the bankruptcies, with an average decline of slightly more than one percent $(-1.09 \%, t=-2.16)$ over the five day window centered on the filing announcement. Most of the creditors experience a decline in value the day before the filing and their stock prices remain depressed for the remainder of the five days. This evidence is consistent with the view that interconnectedness is a 
significant source of contagion for financial firms and thus for financial crises. However, the magnitude of the counterparty contagion effects is small and unlikely to cause additional failures. Further, we note that the market reactions are larger for financial firms than for nonfinancial firms, even though Table III showed that the latter group has larger exposures as a percentage of assets. For example, the day 0 reaction for the financial firms is significant at $-0.91 \%$, but the industrial companies' reaction is insignificant. While interconnectedness among financial firms is more frequently cited as a major factor for the subprime crisis, counterparty contagion effects are not any larger among the bankruptcies that occurred after 2007.

We consider the multivariate analysis of counterparty contagion effects (creditor CARs) in Panels B and C of Table IV. Panel B presents summary statistics on the variables used in the regression while Panel C reports regression estimates. Note from Panel B that the exposure measured as a fraction of total assets averages only $0.93 \%$. The small exposure is not an artifact of small bankrupt firms owing money to large creditors, as the average bankrupt firm has more than $\$ 350$ billion in assets (the largest bankrupt firm is Lehman Brothers) and creditors are almost as large, averaging about $\$ 326$ billion in assets. The largest creditor is Royal Bank of Scotland, which was owed funds by Lehman. The mean exposure is much higher when expressed as a fraction of the market value of the creditor's equity, but at $2.67 \%$ it is still modest. The mean volatility is $3.03 \%$ and the mean equity correlation is 0.24 . About a quarter of the claims are related to derivatives. More than half of the CARs are from recession periods, reflecting the large number of financial firm bankruptcies during the subprime crisis and the credit crunch of 1990-1991. The economic recession intervals are based on the NBER website. ${ }^{21}$

\footnotetext{
${ }^{21}$ http://www.nber.org/cycles/cyclesmain.html.
} 
Panel C of Table IV shows regression estimates to explain the CARs on day 0 and, in model (2), over the five day window including it. Supporting H1, we find that firms with higher counterparty exposures have more negative CARs. In the first three models, we measure exposure as a percentage of the creditor's assets while models (4) and (5) use the equity of the creditor to scale the claims. In all specifications, the results indicate that the more a firm is owed by the bankrupt company the more the stock price of the creditor falls. However, the size of the coefficient is fairly small. For example, using coefficients in model (1), the impact of a one standard deviation increase in the exposure ratio is predicted to reduce the event day AR by only 0.55\%. In models (3) and (5) we restrict the sample period to 2007-2010 to determine if counterparty contagion has a larger effect during the subprime crisis. We find that the coefficients in the later period are nearly identical to those found for the full sample period, although the t-statistics associated with the coefficients are somewhat larger in absolute value. The regressions in Panel C of Table IV control for the sizes of bankrupt firms and creditors, as well as derivatives usage to test H1A's prediction that the impact of counterparty contagion is greater when the bankruptcy involves a large complex financial institution. We do not find significant coefficients on size in any specification. This may reflect the offsetting effects of information since some of the counterparties of the bankrupt firms are also competitors (a large financial firm's bankruptcy may leave greater market share for other firms, leading to positive effects for those stocks). In contrast, we find that creditors with derivatives-related exposures experience more negative reactions than those with other claims, consistent with the view that complex financial institutions impose greater costs on the system when they fail. Derivatives claims that are large have an even greater negative impact on the stock returns of the creditor. However, we note that the derivatives results may also reflect information effects, which are also 
apparent in the correlations of the equity returns of the creditors and debtor companies. If interconnectedness is a major factor in counterparty contagion, then firms with similar use of capital markets should have worse returns as a result of the bankruptcy, and thus we expect the coefficient on the correlation to be negative (i.e., firms with higher correlations should be more adversely affected). Instead, the correlation is usually positive for the event day AR. This might occur if competitive positions of peers cause them to experience less negative effects.

Based on Merton (1974), a creditor that has unusually highly asset volatility and leverage should be more likely to default on its debt. Thus, direct exposure to a failing counterparty is more likely to push firm over the default boundary if the creditor is highly levered or its profits are highly volatile. Volatility has the correct sign and is significant for both stock price reaction metrics. Leverage also has the correct (negative) sign and it is significant using the 5-day CAR.

Importantly, we find that contagion effects are weaker for commercial bank creditors, as shown by the positive coefficients on the commercial bank creditor dummy variable, which are significant during the 2007-2010 subsample. The weaker contagion effect is likely a result of following diversification rules imposed on commercial banks. Finally, bankruptcies that occur in a recession should more often lead to a cascade of failures and we find that the recession indicator is negative and significant for the event day AR.

\section{c. Information contagion and stock market returns of rivals}

Next we investigate information contagion with event studies related to the bankrupt financial firm's competitors that are not its creditors. Table V presents the results. The stock market reactions of all firms in the bankrupt firms' industries indicate that the typical competitor does not experience a significant decline in its market value as a result of the bankruptcy filing. Not only is the average day 0 return on these 142 portfolios insignificant, but none of the event 
windows exhibits a significant negative return. Nor is any other single day return statistically different from zero.

However, we note that the CARs in Table V could be insignificant even though information contagion is important if the tests are not done on the relevant set of competitors or if competitive effects offset negative news about common cash flows. Therefore, we first form portfolios of firms that operate in the same state as the bankrupt firm (and, therefore, which are more likely to be exposed to common regional factors). Table $\mathrm{V}$ shows that the day 0 impact is again estimated at zero for these 96 bankruptcies. However, the CARs for all the longer event windows are significantly negative. Further, the fraction of firms with negative returns is always larger than 50 percent, indicating that the means are not skewed by outliers.

Likewise, we consider whether information contagion is more apparent among competitors that are also focused on real estate. The 89 bankruptcies involving RE firms also involve more information contagion than the sample as a whole, as the day 0 impact is significantly negative (estimated AR is $-0.69 \%$ ) and all four windows reported in this panel of Table V have significant negative t-statistics. The fraction of rival firms with negative returns is also always above half among those rivals that are in the same business as the bankrupt firm. When we narrow the set of competitors down further, by requiring similar geographic markets and a focus on real estate, the estimates do not indicate any significant amount of information contagion. This might be due to offsetting competitive effects for the bankruptcy sample. In untabulated results, we find similar CARs for all of the four categories in Table V when we restrict the period to 2007-2010.

Information contagion may not be as important on the day of a bankruptcy filing as on a day when the losses of the troubled firm have just been revealed to the market. Further, the bankruptcy sample may not reveal as much information to the market as the distressed firm 
sample as the latter group includes TBTF banks. Table VI shows the results of event studies of information contagion for the 149 distressed firms on their worst stock return days. The excess return on day 0 is $-0.63 \%$ and significant. Nearly two thirds of the portfolio has a negative return. The longer windows all show significant negative contagion effects as well. The greater stock market reaction on distress days than on bankruptcy dates is consistent with the theory in Pastor and Veronesi (2012) and the empirical finding of Jorion and Zhang (2007) that intra-industry contagion effects are larger for sudden CDS spread jumps than for Chapter 11 bankruptcy announcements. Our results may also reflect the fact that the distressed firms are still days away from resolving their defaults, reducing the impact of competitive effects (see Zhang (2010)).

As with the bankrupt firm sample, we split the sample to determine how information about distress affects the subset of rivals with similar locations and business lines. The results of our ttests in Table VI show that reactions are sharply higher for firms that are in the same state as the distressed firm (the average day 0 CAR is $-1.37 \%$ and the $[-2,2]$ window CAR is $-2.85 \%$ ). Nearly $70 \%$ of the firms have negative returns. Our sample of distressed firms includes 82 financial institutions that suffered from RE losses. Table VI also shows that the industry response related to these firms' distress is significantly negative on average $(-2.04 \%$ for day 0 and $-2.56 \%$ for the $[-2,2]$ event window) and more than $70 \%$ of the firms have negative returns. When we restrict the portfolios of rival firms' stocks to include those of competitors in the same state and the same line of business, the reactions are even more negative. For this group of firms, the day 0 CAR is $-2.84 \%$ and the CARs over longer windows have magnitudes that exceed $3 \%$. The information contagion effects are notably stronger for firms that encounter difficulty during the subprime financial crisis. The two columns on the far right of Table VI show the mean CARs and the fraction of firms with negative announcement effects for distressed firms during 2007- 
2010. The average CARs range from $-1.51 \%$ to as low as $-9.84 \%$ and the announcement effects are always more negative in the later time period than their counterparts in the overall sample. The percentage of firms with negative announcement effects is comparable in both periods.

Taken together, the results in Tables V and VI suggest that other firms in the industry suffer from stronger contagion effects if they are located in the same state or engage in similar business as the troubled financial firm, as predicted by H3. We examine this hypothesis in greater detail with cross-sectional regressions to explain rival firms' CARs. The explanatory variables, shown in Table VII, include proxies for the similarity of the assets, the size of the troubled firm, the likelihood of default of the peer firm, a dummy variable for recessions and a measure of industry concentration (to control for competitive effects as predicted by H4).

The regressions, reported in Table VIII, also show that information contagion is a factor in cases of financial firm bankruptcies and distress. For each type of event, bankruptcy or distress, we estimate regressions on portfolios of competitor stocks. The portfolios are formed based on whether the stocks are in the same state, RE, or both. No matter how we define similarity (same state, same business or both), the coefficients on the information contagion variables are significant and have the predicted sign after controlling for equity correlations, which have the expected negative sign. In addition, the regressions indicate that the positive competitive effects are small as the Herfindahl measure is only significant in some of the regressions for the bankruptcy sample. Recessions may make information effects even more negative, as this indicator is significant in some specifications of the bankruptcy event regressions. The estimated effects of recessions are consistent with the notion that rivals are less likely to benefit from competitive effects in downturns. 
As we find information contagion is significant for financial firms, we reconsider the results on counterparty contagion to determine if some of the creditor stock returns owe to information contagion as well as counterparty contagion. If information contagion is important for these creditors, their returns should be similar to those of the other firms in the 4-digit SIC code that are not creditors. In contrast, if counterparty contagion accounts for most of the impact on the creditors' stock returns, then the creditors' excess return over the industry average return should be about as large as their market-adjusted returns. In unreported results, we find that the impact of bankruptcy on creditors is largely due to counterparty contagion since the creditors' excess returns over the industry is about the same as the excess returns over the market. For example, the average industry-adjusted portfolio return is $-1.05 \%$ over the $[-2,2]$ window, which is almost the same as the $-1.09 \%$ return over the five day window found in Panel A of Table IV.

\section{d. Robustness Tests}

In this section we consider three types of robustness checks: First we consider the bankruptcies of some large companies as a check on whether the counterparty contagion of our sample is representative of what would happen if a TBTF bank were to go into bankruptcy. Second, we consider whether alternative calculations of excess returns would lead us to draw different conclusions from our event studies. Lastly, we further investigate counterparty risk along the supply chains of bankrupt and distressed firms using data from SEC filings.

A possible explanation for the small effects on counterparties in our data is that most of the bankrupt companies that we study are small. Thus, the results could differ for interconnected firms that transact more often in the capital markets. Similarly, one might expect greater counterparty contagion for creditors that are involved in derivatives with large companies. We address this issue by separately examining data on the creditors of Lehman, AHM, and AIG. In 
addition to being very large firms whose bankruptcies are informative about TBTF cases, Lehman and AHM have the advantage of having more detailed information on claims in the Epiq dataset. ${ }^{22}$ In addition, we are able to identify Lehman creditors from the Daily List of Companies Reporting Lehman Bros. Exposure. ${ }^{23}$ AIG's creditor data comes from Congressional testimony.

\section{$\underline{\text { Lehman }}$}

We present creditor exposures for Lehman in Panel A of Table IX. We note that the largest claim by a publicly traded creditor for Lehman in the table is actually larger than the largest such claim in Table III, even though the latter includes data on Lehman. The reason why this occurs is that the claims in the Epiq dataset are filed by creditors, some of whom asked for compensation on losses related to derivatives contracts above what they could have suffered as a result of the bankruptcy. ${ }^{24}$ We discuss the derivatives in more detail below, but we note that despite their size, the largest claims against Lehman, and the majority of the money, are owed to trustees, as was commonly the case among the firms in Table III. Outside of the trustees, the claims are mostly quite small: The median claim is less than \$5 million and the mean is \$32 million.

\footnotetext{
${ }^{22}$ There are more than 6,500 claims for Lehman, which we obtain from the Epiq. In contrast, the data in Table III (based on 88 bankruptcies, including that of Lehman) is based on the largest unsecured creditors listed in the bankruptcy petition.

${ }^{23}$ See Jorion and Zhang (2012) for more information on this list.

${ }^{24}$ The International Swap Dealers Association (ISDA) master agreement, which applies to nearly all derivatives contracts, and exceptions to the bankruptcy law for derivatives lead to the following outcome in Chapter 11 cases: The counterparty to an ISDA contract with a bankrupt firm chooses whether to continue with the derivative or terminate it. If terminated, the creditor is allowed to keep whatever collateral has so far been posted for the contract. If that collateral is insufficient to cover the creditors' losses, it files a proof of claim for the remainder and that amount is listed among the debtor's unsecured claims. The losses may include the cost of acquiring a replacement contract. These claims appear in the Epiq data as "early termination agreement" claims and they are noted as contingent in the data. The amount of the claim is determined by the fair value of a replacement at the time of the bankruptcy filing.
} 
Lehman also exhibits a high degree of interconnectedness using the number of financial firm creditors as the metric for interconnectedness. Further, claims made by financial firms that are public are substantially above average, with a mean claim size of $\$ 347.1$ million. This result is driven by the average size of derivatives contracts ( $\$ 162.9$ million) and claims that combine bonds with derivatives ( $\$ 1,258.9$ million). These figures are exaggerated in two ways. First, the derivatives claims are overstated, because they fail to adjust the costs for netting. Second, many of the bond claims overstate the true loss from exposure to Lehman because they involve lawsuits about securitization or guarantees from Lehman subsidiaries that did not default.

According to Cameron (2011), the derivative claims are excessive because each derivative loss is affected by the bid-ask spread rather than netted and then adjusted for the bid-ask spread. ${ }^{25}$ Evidence to support this view is the fact that when the Lehman estate disputed many of the derivatives claims, its largest counterparties agreed to substantially revise their claims downward. ${ }^{26}$ Scott (2012) also finds that claims filed against LBHI and its affiliates are approximately four times higher than the most relevant real exposure figures.

\footnotetext{
${ }^{25}$ For example, if a creditor has two CDS contracts with Lehman, one where it is betting that Ford will default and another betting that Ford will not default, then the net claim is zero and the creditor bears no cost in replacing the position. In contrast, the claims filed by creditors are usually filed after each contract's replacement value is calculated (using low bid prices that result from the turmoil in the CDS market), which inflates the aggregate replacement costs of derivatives. Goldman filed a proof of claim that showed that applying the netting procedure prior to making adjustments for bid-ask spreads on its 29,000 derivative contracts would reduce the claim from $\$ 4.2$ billion to $\$ 1.5$ billion.

${ }^{26}$ Summe (2011) discusses the derivatives claims in the case of Lehman and notes they were a major source of recovered assets for Lehman, reaching nearly $\$ 9$ billion. This recovery reflects in large part an agreement among Lehman’s “big bank counterparties” to reduce the claims associated with early termination agreement losses. She includes citations to documents related to the agreement, many of which can be found on the Epiq website. The big bank counterparties were Bank of America, Barclays, BNP Paribas, Citigroup, Credit Suisse, Deutsche Bank, Goldman Sachs, JP Morgan Chase, Merrill Lynch, Morgan Stanley, Royal Bank of Scotland, Societe Generale and UBS.
} 
Even if the derivatives claims actually imposed billions of dollars of losses on those counterparties, these firms' total assets are substantially higher. Panel A of Table IX shows that the typical exposure among public financial firms is very small: the claim as a fraction of assets among the public creditors is typically only . $1 \%$ and even among the financial firms with the large derivatives claims the mean claim is only .5\% of assets. In results not shown, we find that no commercial bank creditor was at risk of losing even $1.5 \%$ of assets to Lehman. Non-bank creditors, which may not face stringent diversification regulations, rarely have exposures that constitute more than $1.5 \%$ of assets. Among the publicly traded financial creditors, $93.2 \%$ have an exposure that is below $1.5 \% .{ }^{27} \mathrm{~A}$ t-test for whether the proportion of such firms with exposures is greater than $1.5 \%$ is rejected with a test statistic of 5.9 .

We also investigate the exposures as a fraction of the market value of the equity of the publicly traded financial firm creditors. Since financial institutions are highly leveraged, it is possible that even a small fraction of assets lent to Lehman could cause some financial firms to fail. We find no evidence that this is the case. The 110 financial creditors are owed only $4.7 \%$ of their equity on average and the median is only $1.1 \%$. While these exposures are small, they are larger than those noted for the sample as a whole in Table III. This could reflect the fact that many financial firms' market capitalizations had declined substantially by the time of the Lehman bankruptcy, but it also owes to the fact that exposures to Lehman were higher as a percent of assets than the typical exposure in Table III. The test statistic for whether the fraction

\footnotetext{
${ }^{27}$ The largest exposure among these firms belongs to GLG Partners, a hedge fund started by Lehman that went public in 2007 and was still 25\% owned by Lehman in September 2008.
} 
of equity exposed to Lehman is above $15 \%$ is 8.5 , rejecting the hypothesis that creditors of Lehman’s bankruptcy typically defy diversification rules. ${ }^{28}$

The largest exposures as a percent of assets are found among nonfinancial firms, which are less often regulated and therefore under less pressure to diversify their assets. In addition, they may find it optimal to have large exposures to other firms as suppliers or customers. Thus, as many as a quarter of the industrial creditors of Lehman have claims that exceed $1.5 \%$ of assets and a t-test for whether the mean exposure exceeds $1.5 \%$ cannot be rejected. While the mean exposure is greatest among this group, it nonetheless only accounts for $4 \%$ of their assets on average and the median exposure is only $0.1 \%$ of assets. The largest of the exposures, $90.4 \%$, belongs to 4Kids Entertainment, a toy company that lost money when it invested its working capital in auction rate securities on Lehman’s advice and subsequently sued. ${ }^{29}$ In dollar amounts, the largest claim by a nonfinancial firm belongs to Dynergy, an active participant in the energy derivatives market.

Eight creditors of Lehman filed for Chapter 11 or Chapter 7 bankruptcy (including Nortel which filed in Canada). One creditor is a hedge fund (Anthracite Investments), one is a bank

\footnotetext{
${ }^{28}$ In addition to the derivatives claims, proof of claims are often inflated by claims for damages that would ordinarily be sought via a lawsuit. The largest Lehman creditor that is not a trustee is Fannie Mae, which filed a proof of claim form stating that it was owed over \$15 billion, including two claims related to mortgage-backed security (MBS) transactions. The claim was essentially an inexpensive way for Fannie Mae to file a lawsuit alleging Lehman misconduct in creating MBS (see Helwege (1999)). In addition to lawsuits, the bonds and derivatives claims are larger than other claims in part because of guarantees. If a subsidiary of Lehman does not file for bankruptcy and it continues to make payments on a bond that it issued, the entire bond will still be included in the bankruptcy if Lehman guarantees the bond of the subsidiary. This is because the subsidiary might go bankrupt some day for other reasons and their creditors at that point would want any assets that are available from the parent.

${ }^{29}$ 4Kids suffered these losses in summer 2008 and the suit began before the bankruptcy filing. The claim was for losses of $\$ 31.5$ million in principal, interest of $9 \%$ and treble damages of about $\$ 95$ million.
} 
(Co-operative Bank, PLC), another is a municipal bond insurer (Ambac) and the rest are nonfinancial firms. Two industrial firms, Dynergy and 4Kids Entertainment, with large exposures to Lehman, did collapse after the Lehman filing, but their failures in 2011 did not occur suddenly. Thus, the subsequent bankruptcies of Lehman’s creditors are also not well described as a cascade of Ch. 11 filings of interconnected capital market participants. Royal Bank of Scotland is the only large financial firm creditor of Lehman to fall into distress after September 2008. ${ }^{30}$ These findings support Scott's (2012) conclusion that interconnectedness was not the primary driver of systemic risk following the collapse of Lehman.

One Lehman creditor not mentioned so far (because it is not publicly traded ) that can clearly be described as failing due to the bankruptcy is the Reserve Primary Fund (RPF), a money market mutual fund (mmmf) that "broke the buck” as a result of its losses on \$785 million of Lehman debt. As Fisch and Roiter (2012) note, “the RPF loss was a rather modest one: the fund ultimately lost less than $1 \%$ of its overall value. ${ }^{31}$ However, SEC rules for mmmfs require that they maintain an NAV of at least 99.5 cents and when they fall below the minimum the SEC-sanctioned policy is to suspend redemptions and liquidate the fund. According to Fisch

\footnotetext{
${ }^{30}$ A possible concern with this finding is whether a cascade of failures was avoided when the central bank intervened starting in fall 2008. We note that the exposures were quite small at the time of the bankruptcy so even if those firms had not received a bailout they would not have gone under as a result of counterparty exposures. Furthermore, few of the institutions that received large bailouts in fall 2008 were listed as unsecured creditors in the Chapter 11 filing. For example, of the nine financial institutions that received $\$ 125$ billion in capital through TARP in October 2008 (Merrill Lynch, Goldman, Morgan Stanley, JP Morgan, Bank of America, Citigroup, Wells Fargo, and Bank of New York Mellon), only Citigroup and BONY were listed by Lehman as unsecured creditors in its Chapter 11 filing and both served as trustees for bondholders. While seven of the nine (Wells and BONY were the exceptions) were derivatives creditors that subsequently filed proofs of claims (available in the Epiq data), these claims only totaled about $\$ 10$ billion and they were reduced sharply as part of the Big Bank Counterparties settlement (see footnote 30). We note that AIG, which received an $\$ 85$ billion bailout in September 2008, was not a Lehman creditor.

${ }^{31}$ See Kacperczyk and Schnabl (2013) also.
} 
and Roiter (2012), investors in the RPF lost the liquidity of their investment for almost a year. Thus, while the trigger for RPF's demise was Lehman's bankruptcy, one could argue that its failure owed more to the rigidity of the NAV rule and the SEC suspension policy.

$\underline{A H M}$

Panel B of Table IX presents comparable results for AHM, which has no data on exposures in bankruptcydata.com and thus is not part of the results in Table III. AHM is an interesting case because it filed for bankruptcy on August 7, 2007 as a result of losses on Alt-A loans. As one of the country's largest mortgage originators, its demise was widely reported as a sign that trouble in the subprime market had spread to better quality loans. ${ }^{32}$ As Panel B shows, most of its unsecured creditors are financial firms, and a large fraction of these are commercial banks (SIC 6020), thrifts (6035) and investment banks (6211), the industries that are most often associated with systemic risk. Yet, the exposures of these firms are small, typically well under \$50 million and always well under $1.5 \%$ of assets and $15 \%$ of equity. Notably, the repurchase (repo) claims are also small, as these are typically secured loans and the unsecured claims related to repos represent losses from insufficient collateral, not the full extent of the repo loan.

\section{$\underline{A I G}$}

AIG's creditors have much larger exposures than any of those reported for Lehman and AHM (Panel C of Table IX), which supports the government's claim that AIG would have had a greater impact on the financial system. Moreover, Panel C shows that the vast majority of the exposures are among commercial and investment banks, further bolstering the view that AIG was systemically important. The largest exposures involve sophisticated capital markets

\footnotetext{
${ }^{32}$ AHM's employee base of about 7500 workers was hacked down to only 750 just a few days before its Chapter 11 filing, reflecting severe funding problems. See USA Today (2007).
} 
instruments, such as CDS, repurchases and CDOs. However, the counterparties to AIG are among the largest financial institutions in the world, so even with exposures as high as $\$ 7$ billion for a single firm, none of the exposures exceed $1.5 \%$ percent of the creditor's assets. Typically, the potential losses are no more than a half percent of assets, which supports Goldman Sachs' claim that it "had no material direct economic exposure to AIG." ${ }^{\text {"33 }}$ Measured by the market value of equity, the claims are substantially higher and Goldman's statement is far less credible, as the table shows that the exposures as a fraction of the market value of equity of the creditor are sometimes as high as $27 \%$. Goldman's claims on AIG amounted to more than $20 \%$ of its equity at the end of the second quarter of 2008. Nonetheless, the loss of equity would not be sufficient by itself to push Goldman or any other AIG counterparty into bankruptcy.

The event study evidence on counterparty contagion suggests such effects are modest in our sample, so a natural consideration is whether contagion is more readily apparent when we examine the cases of Lehman and AIG. In Table $\mathrm{X}$ we investigate the impact of various negative news days on their respective counterparties. For Lehman, we investigate six dates in 2008: March 14 (the Bear Stearns deal), June 2 (ratings downgrade), June 9 (announcement of major losses), August 19 (secret talks to raise capital stall), September 11 (news about a search for a buyer) and September 15 (bankruptcy). For AIG, we examine four earnings announcement dates between 2007 and its bailout in September 2008, each with a negative earnings surprise, and the two dates involving financial problems at AIG (February 11, 2008 and September 15, 2008) analyzed by Egginton et al. (2010). ${ }^{34}$

\footnotetext{
${ }^{33}$ See http://www2.goldmansachs.com/media-relations/comments-and-responses/archive/aig-summary.html.

${ }^{34}$ Lehman reported losses in advance of earnings releases, so its announcement dates are less informative.
} 
Panel A indicates that counterparty contagion has a significant impact on the stock returns of Lehman's creditors and the point estimates for the five day announcement window are nearly double those of the full sample reported in Panel A of Table IV. The stock returns of Lehman's creditors fall by $1.24 \%$ on average over days 0 and 1 with a t-statistic of -3.33 . The largest negative returns occur on September 11, 2008, with the event day AR of $-1.42 \%$ and the 3-day CAR of $-3.09 \%(t=-2.94)$. Much of the creditor portfolio response occurs within the financial firm creditors, despite the fact that Table IX, Panel A shows that nearly all of their claims are less than $1.5 \%$ of assets. Compared to the $4.7 \%$ mean exposure as a fraction of equity, the declines in the counterparties' market values are somewhat high, which could be due to information about the loss of future business. As shown in the rightmost two columns, the firms with the largest exposures, whether measured by assets or market value of equity, have the largest stock market reactions to the bankruptcy filing and their stock prices fall by as much as $3.87 \%$ over the five day announcement window.

The collapse of AIG has a much larger impact than average on the firm's counterparties. Panel B of Table X shows that for AIG's creditors, the effect over the five day announcement window is $-4.24 \%$. The returns are noticeably lower for the creditors with higher exposures. These six event days' losses caused an average cumulative loss of nearly one-quarter of the equity of AIG's creditors, including a loss of more than $10 \%$ around the distress day in September 2008. ${ }^{35}$ After AIG's bailout, creditors experienced huge positive abnormal returns (8.63\% on day 1 and $9.53 \%$ on day 2 ), which is also consistent with a major role for counterparty

\footnotetext{
${ }^{35}$ This result should be interpreted with caution because the AIG's distress day is also the Lehman's bankruptcy day and thus there may be confounding effects.
} 
contagion. These results suggest counterparty contagion from a large financial institution is a serious concern for other financial firms during a financial crisis.

Our second robustness check involves alternative event study methodologies for the counterparty contagion analysis. For example, Table IV shows creditor stock returns using portfolios of firms. An alternative approach is to treat each creditor firm separately and calculates the average AR and CAR across creditors. In unreported results, we find that this approach yields estimates of counterparty contagion effects that are slightly larger: rather than an average return of -1.05 over the $[-2,2]$ event window, the return is $-2.29 \%(t=-4.37)$ and if we restrict the sample to financial creditors the average is $-2.43 \%(\mathrm{t}=-3.70)$. We also repeat these event studies using the Fama-French and the 4-factor models to calculate excess returns and we find that the (unreported) results are similar.

Next, we consider whether the stock market reaction to the bankruptcy filings is limited for counterparties because investors are unaware of the exposures and the risk associated with them. The logic behind this concern assumes that even after the company files its bankruptcy petition listing its largest unsecured creditors the counterparty shareholders are unaware of the risk. The fact that so many companies reported the true nature of their Lehman exposures to the Wall Street Journal (the basis of the Dow Jones report used by Jorion and Zhang (2012)) suggests that investors do become aware of the exposures from the bankruptcy filing. Moreover, these data also indicate that the exposures are quite small.

Investors may be less informed about the degree of interconnectedness of financial institutions in the case of distressed firms. We note, however, that all of the publicly traded companies in our sample of counterparties are required to report material risks in their $10-\mathrm{K}$ filings related to important business relationships. Therefore, if the distressed firms are more 
interconnected than our bankrupt firms or AIG, these exposures should be reported to their shareholders as a matter of course. Following the strategy of Fee and Thomas (2004) and Hertzel, Li, Officer and Rodgers (2008), we identify relationships using the Compustat segment files from 1979-2010. Then we match the names of the customers and suppliers to our lists of bankrupt and distressed firms to determine the extent to which these troubled financial firms might have caused serious problems along the supply chain.

These public documents provide little evidence of interconnectedness, as few of our bankrupt firms' names in the lists of major customers and suppliers in Compustat. Five companies list one of our bankrupt firms as important customers in their 10-K forms. However, none of the five firms were involved in derivatives trading or interbank lending. ${ }^{36}$ Firms that list our bankrupt firms as suppliers are equally rare. Of these, only American Home Mortgage’s SEC filings suggest an important supplier-customer relationship with financial firms in the crisis period.

The distressed firms are typically larger than the bankrupt firms and they are more often listed as important customers in the SEC data. We find 40 of the distressed firms are listed as important sources of revenue for 133 firms in a total of 373 reports, but these firms are rarely connected through capital market transactions. ${ }^{37}$ Of the 118 instances where a distressed firm is listed by a financial firm, only 17 are in SEC filings after 2006 and these more often involve insurance companies. We also investigate our distressed firms to check whether they disclose business relationships with financial firms in their SEC filings, but only three firms do and these

\footnotetext{
${ }^{36}$ Three were nonfinancial firms while Clayton Holdings worked on due diligence in the issuance of Lehman MBS and Vornado is a REIT that had Lehman as a tenant.

${ }^{37}$ For example, the 40 distressed firms include AIG, Citigroup, Bear Stearns, and Royal Bank of Scotland but none of these four firms is listed by a major financial firm near the time of the crisis.
} 
are all mortgage originators that sell to Bank of America, Wells Fargo and Fannie Mae for MBS issuance. In untabulated results, we do not find significant equity valuation effects along the supply chain for bankrupt and distressed firms. In sum, these results also indicate that the potential for counterparty contagion to cause a cascade of financial failures is small.

\section{Conclusion}

The recent financial crisis raises the question of why markets collapse after a major financial firm files for bankruptcy or becomes distressed. Early studies of the spillover effects of bankruptcies, which were mainly based on samples of nonfinancial firms, focused on the information transmitted by such events. While the same effects could be equally important when financial firms go bankrupt or become distressed, the recent financial crisis has focused researchers' attention on the potential for counterparty contagion. If counterparty contagion is a major factor in cases of distressed financial firms, then government liquidity programs directed at their creditors may substantially reduce the adverse impact of such failures on markets. Thus, we evaluate information contagion and counterparty contagion to determine how these two sources of contagion affect other financial firms.

We find that counterparty contagion is stronger for firms with larger and more complex exposures, higher equity return volatilities and during recessions, while it is weaker for commercial banks. The counterparty contagion effect is generally limited in magnitude, which owes to the fact that most counterparties have rather small exposures to the bankrupt companies. The largest exposures, revealed in the list of the largest unsecured creditors in the bankruptcy petition, often belong to the trustees of publicly traded bonds and since these bonds are widely held, the exposure of a single financial firm is substantially smaller. Other creditors are often 
financial firms, suggesting highly interconnected financial institutions. But financial creditors are rarely at risk of failing as a result of another firm's troubles because these firms hold diversified portfolios, as is often required by regulation. Our results point to the importance of diversification regulations for financial firms as a method for mitigating systemic risk.

Information contagion is also a significant channel of contagion. When we examine rivals of bankrupt firms located in the same state or same line of business, the magnitude of the effects on rivals is comparable to that found for creditors. We also investigate information contagion using a sample of distressed firms and find that information contagion is markedly higher in cases of distress than at the time of the bankruptcy filing. These effects are also higher for rivals that operate in similar geographic locales and in the same line of business, such as real estate. Our results on information contagion suggest that financial crises may be attributable to similar portfolio decisions by a number of financial firms that are revealed to be unsuccessful. When the market learns about these problems from their failures, it penalizes other firms with similar characteristics. If these firms represent a large fraction of the financial sector, their losses may justify temporary central bank liquidity facilities as asset prices stabilize. 


\section{References}

Acharya, V., C.T. Brownlees, R. Engle, F. Farazmand, and M. Richardson, 2010, Measuring Systemic Risk, in 'Regulating Wall Street: The Dodd-Frank Act and the New Architecture of Global Finance', Wiley.

Adrian, T. and M. Brunnermeier, 2010, CoVar, working paper.

Aharony, J. and I. Swary, 1983, Contagion Effects from Bank Failures: Evidence from Capital Markets, Journal of Business, 56, 305-322.

Aharony, J. and I. Swary, 1996, Additional Evidence on the Information-based Contagion Effects of Bank Failures, Journal of Banking and Finance, 20, 57-69.

Allen F. and D. Gale, 2000, Financial Contagion, Journal of Political Economics, 108, 1-33.

Allen F., A. Babus and E. Carletti, 2009, Financial Crises: Theory and Evidence, Annual Review of Financial Economics, 1, 97-116.

Aragon, G.O. and P.E. Strahan, 2012, Hedge Funds as Liquidity Providers: Evidence from the the Lehman Bankruptcy, Journal of Financial Economics, 103, 570-586.

Arora, N., P. Gandhi and F.A. Longstaff, 2012, Counterparty Credit Risk and the Credit Default Swap Market, Journal of Financial Economics, 103, 28-293.

Bai, J., P. Collin-Dufresne, R. Goldstein, and J. Helwege, 2012, On Bounding Credit Event Risk Premia, working paper.

Benzoni, L., P. Collin-Dufresne, R. Goldstein, and J. Helwege, 2012, Modeling Credit Contagion via the Updating of Fragile Beliefs, working paper.

Billio, M., M. Getmansky, A.W. Lo, and L. Pelizzon, 2012, Econometric Measures of Systemic Risk in the Finance and Insurance Sectors, Journal of Financial Economics 104, 535-559 
Boyson, N., C.W. Stahel, and R.M. Stulz, 2010, Hedge Fund Contagion and Liquidity Shocks, Journal of Finance, 65, 1789-1816.

Brunnermeier, M., 2009, Deciphering the liquidity and credit crunch 2007-2008, Journal of Economic Perspectives 23, 77-100.

Brunnermeier, M. and L.H. Pedersen, 2009, Market Liquidity and Funding Liquidity, Review of Financial Studies, 22, 2201-2238.

Cameron, M., 2011, LBHI Administrators Push for Settlement of Derivatives Claims, Risk, March 2.

Cecchetti. S.G., J. Gyntelberg and M. Hollanders, 2009, Central counterparties for over-thecounter derivatives, Bank for International Settlements Quarterly Review, September.

Chakrabarty. B., and G. Zhang, 2012, Credit Contagion Channels: Market Microstructure Evidence from Lehman Brothers’ Bankruptcy, Financial Management, 41, 320-343.

Cole, R.A. and L.J. White, 2012, Déjà Vu All over Again: The Causes of Commercial Bank Failures This Time Around, Journal of Financial Services Research, 42, 5-29.

Cooper, I. and A. Mello, 1991, The Default Risk on Swaps, Journal of Finance, 46, 597-620.

Covitz, D., N. Liang, and G. Suarez, 2012, The Evolution of a Financial Crisis: Runs in the Asset-Backed Commercial Paper Market, Journal of Finance, forthcoming.

Das, S., D. Duffie, N. Kapadia, and L. Saita, 2007, Common Failings: How Corporate Defaults are Correlated, Journal of Finance 62, 93-117.

Davis, M. and V. Lo, 2001, Infectious Defaults, Quantitative Finance 1, 382-387.

Dickinson, A., D.R. Peterson, and W.A. Christiansen, 1991, An Empirical Investigation into the Failure of First Republic Bank: Is There a Contagion Effect? Financial Review, 26, 303318. 
Dudleya E. and M. Nimalendrana, 2011, Margins and Hedge Fund Contagion, Journal of Financial and Quantitative Analysis, 46, 1227-1257.

Duffie, D., A. Eckner, G. Horel, and L. Saita, 2009, Frailty Correlated Default, Journal of Finance, 2009, 64, 2089-2124.

Duffie, D. and H. Zhu, 2012, Does a Central Clearing Counterparty Reduce Counterparty Risk?, Review of Asset Pricing Studies, 1, 74-95.

Drehmann, M and N Tarashev, 2011, Measuring the Systemic Importance of Interconnected Banks, Working paper.

Economic Report of the President, 2010, available at http://www.whitehouse.gov/sites/default/files/microsites/economic-report-president.pdf

Egginton, J., J.I. Hilliard, A.P. Liebenberg, and I.A. Liebenberg, I.A., 2010, What Effect did AIG’s Bailout, and the Preceding Events, Have on its Competitors?, Risk Management and Insurance Review, 2, 225-249.

Eisenberg, L. and T. H. Noe, 2010, Systemic Risk in Financial Systems, Management Science, 47, 236-249.

Fee, C. and S. Thomas, 2004, Sources of Gains in Horizontal Mergers: Evidence from Customer, Supplier, and Rival Firms, Journal of Financial Economics, 74, 423-460.

Fenn, G., and R. Cole, 1994, Announcements of Asset Quality Problems and Contagion Effects in the Life Insurance Industry, Journal of Financial Economics, 35, 181-198.

Fernando, C., A. May, and W. Megginson, 2012, The Value of Investment Banking Relationships: Evidence from the Collapse of Lehman Brothers, Journal of Finance, 67, 235-270. 
Fields, J.A., J.B. Ross, C. Ghosh, and K.B. Johnson, 1994, Junk Bonds, Life Insurer Insolvency, and Stock Market Reactions: The Case of First Executive Corporation, Journal of Financial Services Research, 8, 95-111.

Fields, J.A., L.S. Klein, and E. Myskowski, 1998, Lloyd's Financial Distress and Contagion within the US Property and Liability Insurance Industry, Journal of Risk and Uncertainty, $16,173-185$.

Fisch, J.E. and E.D. Roiter, 2012, A Floating NAV for Money Market Funds: Fix or Fantasy? University of Illinois Law Review, 4, 1003-1050.

Flannery, M.J., 1998, Using Market Information in Prudent Bank Supervision: A Review of the U.S. Empirical Evidence, Journal of Money, Credit and Banking, 30, 273-305.

Furfine, C.H., 2003, Interbank Exposures: Quantifying the Risk of Contagion, Journal of Money, Credit and Banking, 35, 111-128.

Gieseceke, K., 2004, Correlated Default with Incomplete Information, Journal of Banking and Finance, 28, 1521-1545.

Gieseceke, K. and S. Weber, 2004, Cyclical Correlations, Credit Contagion, and Portfolio Losses, Journal of Banking and Finance, 25, 3009-3036.

Giglio, S., 2011, Credit Default Swap Spreads and Systemic Financial Risk, Working paper.

Gilson, S.C., 1989, Management Turnover and Financial Distress, Journal of Financial Economics, 25, 241-262.

Gorton, G. and A. Metrick, 2012, Securitized banking and the run on repo. Journal of Financial Economics, 104, 425-451.

Han, S. and X. Zhou, 2009, Information Asymmetry in Corporate Bond Trading, Credit Risk, and Yield Spread, working paper. 
Helwege, J., 1999, How Long Do Junk Bonds Spend in Default?, Journal of Finance, 54, 341357.

Helwege, J., 2010, Financial Firm Bankruptcy and Systemic Risk, Journal of International Financial Markets, Institutions, and Money, 33, 231-261.

Hertzel, M., and M. Officer, 2012, Industry Contagion in Loan Spreads, Journal of Financial Economics, 103, 493-506.

Hertzel, M., Z. Li, M. Officer and K. Rodgers, 2008, Inter-firm Linkages and the Wealth Effects of Financial Distress along the Supply Chain, Journal of Financial Economics, 87, 374387.

Huang, X., H. Zhou, and H. Zhu, 2009, A Framework for Assessing the Systemic Risk of Major Financial Institutions, Journal of Banking and Finance, 33, 2036-2049.

Ivashina, V. and D. Scharfstein, 2010, Bank Lending during the Financial Crisis of 2008, Journal of Financial Economics, 97, 319-338.

Iyer, R., and J. L. Peydró, 2011, Interbank Contagion at Work: Evidence from a Natural Experiment, Review of Financial Studies 24, 1337-1377.

Jarrow, R. and F. Yu, 2001, Counterparty Risk and the Pricing of Defaultable Securities, Journal of Finance 56, 1765-1799.

Jorion, P. and G. Zhang, 2007, Good and Bad Credit Contagion: Evidence from Credit Default Swaps, Journal of Financial Economics, 84, 860-883.

Jorion, P. and G. Zhang, 2009, Counterparty Risk, Journal of Financial Economics, 64, 20532087.

Jorion, P. and G. Zhang, 2012, Financial Contagion and Lehman Brothers’ Bankruptcy, working paper. 
Kacperczyk, M. and P. Schnabl, 2010, When Safe Proved Risky: Commercial Paper during the Financial Crisis of 2007-2009, Journal of Economic Perspectives, 24, 29-50.

Kacperczyk, M. and P. Schnabl, 2013, How Safe are Money Market Funds?, forthcoming Quarterly Journal of Economics.

Kahle, K.M. and R.A. Walkling, 1996, The Impact of Industry Classifications on Financial Research, Journal of Financial and Quantitative Analysis, 31, 309-335.

Karafiath, I. and J. Glascock, 1989, Intra-Industry Effects of a Regulatory Shift: Capital Market Evidence from Penn Square, Financial Review, 24, 123-134.

King, M.A., and S. Wadhwani, 1990, Transmission of Volatility between Stock Markets, Review of Financial Studies, 3, 5-33.

Kodres, L.E. and M. Pritsker, 2002, A Rational Expectations Model of Financial Contagion, Journal of Finance, 57, 769-799.

Kraft, H. and M. Steffensen, 2007, Bankruptcy, Counterparty Risk and Contagion, Review of Finance, 11, 209-252.

Lando, D. and M. S. Nielsen, 2010, Correlation in corporate defaults: Contagion or conditional independence? Journal of Financial Intermediation, 19, 355-372.

Lang, L.H.P. and R.M. Stulz, 1992, Contagion and Competitive Intra-Industry Effects of Bankruptcy Announcements, Journal of Financial Economics, 32, 45-60.

Longstaff, .F.A., 2010, The Subprime Credit Crisis and Contagion in Financial Markets, Journal of Financial Economics, 97, 436-450.

MacKinley, A.C, 1997, Event Studies in Economics and Finance, Journal of Economic Literature, 35, 13-39. 
Massa, M., A. Yasuda, and L. Zhang, 2010, Investment Horizon of the Bond Investor Base and the Leverage of the Firm, working paper.

Merton, R., 1974, On the Pricing of Corporate Debt: The Risk Structure of Interest Rates, Journal of Finance, 29, 449-470.

Mitchell, M. and T. Pulvino, 2012, Arbitrage Crashes and the Speed of Capital, Journal of Financial Economics, 104, 469-490.

Pastor, L. and P. Veronesi, 2012, Uncertainty about Government Policy and Stock Prices, Journal of Finance, 67, 1219-1264.

Pirrong, C., 2009, The Inefficiency of Clearing Mandates, Policy Analysis, 665, 1-39.

Pirinsky, C. and Q. Wang, 2006, Does Corporate Headquarters Location Matter for Stock Returns? Journal of Finance, 61, 1991-2015.

Rochet, J., 2010, Systemic Risk: Changing the Regulatory Perspective, International Journal of Central Banking, 6, 259-276.

Rochet, J. and J. Tirole, 1996, Interbank Lending and Systemic Risk, Journal of Money, Credit and Banking, 28, 733-762.

Slovin, M., M. Shushka, and J. Polenchek, 1999, An Analysis of Contagion and Competitive Effects at Commercial Banks, Journal of Financial Economics, 54, 197-225.

Shleifer, A., and R. W. Vishny, 2011, Fire Sales in Finance and Macroeconomics, Journal of Economic Perspectives, 25, 29-48.

Staum, J. C. Counterparty Contagion in Context: Contributions to Systemic Risk, working paper.

Strahan, P.E. and B. Tanyeri, 2013. Once Burned, Twice Shy: Money Market Fund Responses to a Systemic Liquidity Shock, Journal of Financial and Quantitative Analysis, forthcoming. 
Suh, S., 2011, An Analysis of Contagion and Competitive Effects at Commercial Banks, Journal of Financial Intermediation, 24, 341-358.

Summe, K., 2011, Misconceptions about Lehman Brothers Bankruptcy and the Role Derivatives Played, Stanford Law Review Online, 64, 16-21.

Theocharides, G., 2008, Contagion: Evidence from the Bond Market, working paper.

USA Today, 2007, American Home Mortgage Files for Bankruptcy, August 7.

Veronesi, P., 2000, How Does Information Quality Affect Stock Returns? Journal of Finance, $55,807-837$.

Wagner, W., 2011, Systemic Liquidation Risk and the Diversity-Diversification Trade-off, Journal of Finance 64, 1141-1175.

Yang, J. and Y. Zhou, 2012, Credit Risk Spillovers among Financial Institutions around the Global Credit Crisis: Firm Level Evidence, Management Science, forthcoming.

Zhang, G., 2010, Emerging from Chapter 11 Bankruptcy: Is It Good News or Bad News for Industry Competitors? Financial Management, 39, 1719-1742. 
Table I

\section{Distribution of Bankruptcy and Distress Events in Sample}

The sample is from 1981 to 2010 and includes 142 bankrupties and 149 distress events with industry portfolio information on CRSP and COMPUSTAT.

Industry is defined by 4-digit SIC codes.

\begin{tabular}{|c|c|c|}
\hline \multicolumn{3}{|c|}{ Panel A: Number of Events by Year } \\
\hline Year & Bankruptcies & Distress \\
\hline 1981 & 1 & 0 \\
\hline 1982 & 0 & 1 \\
\hline 1983 & 0 & 0 \\
\hline 1984 & 0 & 2 \\
\hline 1985 & 0 & 0 \\
\hline 1986 & 1 & 0 \\
\hline 1987 & 0 & 4 \\
\hline 1988 & 4 & 4 \\
\hline 1989 & 8 & 4 \\
\hline 1990 & 10 & 6 \\
\hline 1991 & 7 & 9 \\
\hline 1992 & 2 & 5 \\
\hline 1993 & 4 & 1 \\
\hline 1994 & 1 & 3 \\
\hline 1995 & 3 & 2 \\
\hline 1996 & 0 & 0 \\
\hline 1997 & 3 & 0 \\
\hline 1998 & 7 & 1 \\
\hline 1999 & 4 & 3 \\
\hline 2000 & 6 & 6 \\
\hline 2001 & 6 & 7 \\
\hline 2002 & 6 & 16 \\
\hline 2003 & 3 & 7 \\
\hline 2004 & 1 & 4 \\
\hline 2005 & 3 & 3 \\
\hline 2006 & 2 & 3 \\
\hline 2007 & 7 & 15 \\
\hline 2008 & 10 & 28 \\
\hline 2009 & 25 & 12 \\
\hline 2010 & 18 & 3 \\
\hline Total & 142 & 149 \\
\hline
\end{tabular}

Panel C: Distribution of Events by State

\begin{tabular}{ccc}
\hline Location & $\begin{array}{c}\text { Bankruptcy } \\
\text { Sample }\end{array}$ & $\begin{array}{c}\text { Distress } \\
\text { Sample }\end{array}$ \\
\hline California & 36 & 20 \\
New York & 24 & 26 \\
Texas & 15 & 10 \\
Florida & 12 & 9 \\
Illinois & 7 & 6 \\
Georgia & 5 & 1 \\
Alabama & 4 & 1 \\
Arizona & 3 & 3 \\
Kansas & 3 & 0 \\
North Carolina & 3 & 0 \\
Washington & 3 & 3 \\
Pennsylvania & 2 & 6 \\
Virginia & 1 & 5 \\
Puerto Rico & 1 & 5 \\
Connecticut & 0 & 4 \\
Ohio & 0 & 4 \\
Massachusetts & 0 & 3 \\
DC & 0 & 3 \\
Wisconsin & 0 & 3 \\
Other State & 23 & 16 \\
Foreign & 0 & 21 \\
\hline & &
\end{tabular}

\begin{tabular}{|c|c|c|c|}
\hline \multicolumn{4}{|l|}{ Panel B: Number of Firms by Industry } \\
\hline & Industry & Bankruptcy & Distress \\
\hline \multicolumn{4}{|l|}{ Depository Institutions } \\
\hline Commercial Banks & 6020 & 34 & 47 \\
\hline Federally Chartered Thrifts & 6035 & 11 & 17 \\
\hline Other Thrifts & 6036 & 8 & 10 \\
\hline \multicolumn{4}{|l|}{ Non-depository Credit (Finance Companies) } \\
\hline Government-sponsored Enterprises & 6111 & 0 & 5 \\
\hline Personal Finance Companies & 6141 & 10 & 2 \\
\hline Business Finance Companies & 6153 & 2 & 0 \\
\hline Captive Finance Companies and Others & 6159 & 4 & 2 \\
\hline Mortgage Bankers & 6162 & 11 & 4 \\
\hline Leasing Companies & 6172 & 3 & 0 \\
\hline \multicolumn{4}{|l|}{ Securities Firms } \\
\hline Brokers and Dealers & 6200 & 1 & 0 \\
\hline Investment Banks & 6211 & 8 & 5 \\
\hline Investment Advice & 6282 & 2 & 3 \\
\hline \multicolumn{4}{|l|}{ Insurance Companies } \\
\hline Life Insurers & 6311 & 4 & 14 \\
\hline Accident and Health Insureres & 6321 & 1 & 2 \\
\hline Hospital and Medical Plans & 6324 & 0 & 1 \\
\hline Property and Casualty Insurers & 6331 & 9 & 8 \\
\hline Surety Insurance Firms & 6351 & 2 & 5 \\
\hline Title Insurance Firms & 6361 & 1 & 0 \\
\hline Insurance Agents & 6411 & 3 & 3 \\
\hline \multicolumn{4}{|l|}{ Real Estate } \\
\hline Real Estate Operators & 6510 & 2 & 0 \\
\hline Commercial Property Operators & 6512 & 2 & 1 \\
\hline Apartment Building Operators & 6513 & 1 & 0 \\
\hline Real Estate Dealers & 6532 & 3 & 0 \\
\hline Land Developers & 6552 & 3 & 0 \\
\hline \multicolumn{4}{|l|}{ Financial Holding Companies } \\
\hline Real Estate Investment Trusts (REITs) & 6798 & 16 & 18 \\
\hline \multirow[t]{2}{*}{ Miscellaneous Financial Holding Companies } & 6799 & 1 & 2 \\
\hline & Total & 142 & 149 \\
\hline
\end{tabular}

Panel D: Number of Firms in Real Estate Business

\begin{tabular}{|c|c|c|c|c|}
\hline & Number & Percentage & & \\
\hline Bankrupt firms & 94 & $66.2 \%$ & & \\
\hline Distressed firms & 83 & $55.7 \%$ & & \\
\hline \multicolumn{5}{|c|}{ Panel E: Total Assets of Event Firms (\$ millions) } \\
\hline & Mean & Median & Max & Min \\
\hline Bankrupt firms & 12231 & 1066 & 691063 & 0 \\
\hline Distressed firms & 73243 & 11701 & 1706787 & 3382 \\
\hline
\end{tabular}


Table II

Sizes of Samples of Affected Firms

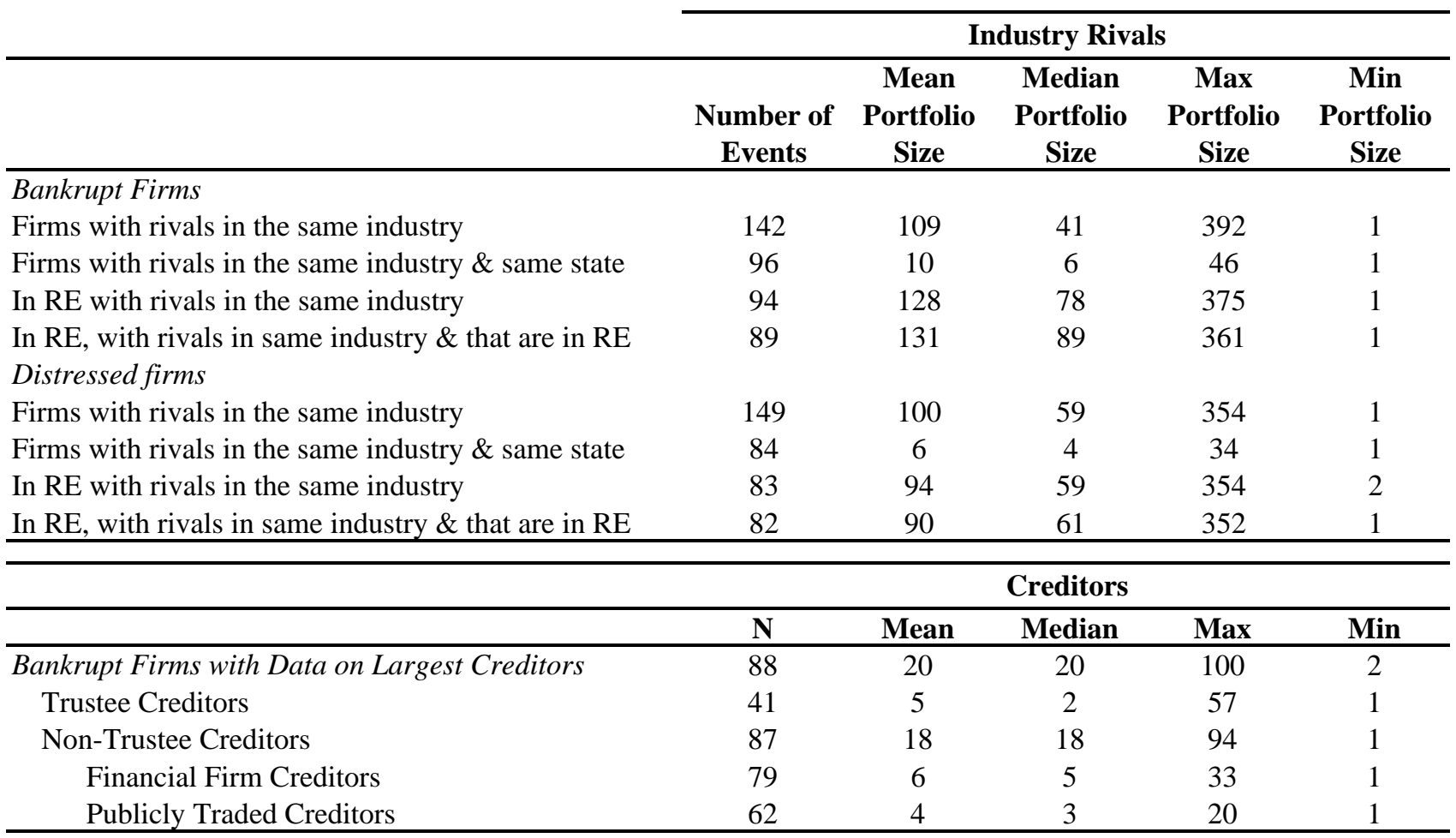




\section{Table III}

\section{Debt Owed to Unsecured Creditors}

Panel A. Aggregate debt amount per bankruptcy (\$mm)

\begin{tabular}{lcccccc}
\hline & N & Total & Mean & Median & Max & Min \\
\hline All Bankruptcies & 88 & $256,459.2$ & $2,914.3$ & 77.6 & $157,917.0$ & 0.1 \\
With Trustee Creditors & 41 & $226,647.7$ & $5,528.0$ & 143.1 & $155,000.0$ & 0.2 \\
With Non-Trustee Creditors & 87 & $29,811.5$ & 342.7 & 40.1 & $3,729.9$ & 0.0 \\
$\quad$ With Financial Firm Creditors & 79 & $27,197.0$ & 344.3 & 14.9 & $3,514.9$ & 0.0 \\
\hline
\end{tabular}

Panel B. Amount owed to financial institution creditors

\begin{tabular}{|c|c|c|c|c|c|c|}
\hline & $\begin{array}{l}\text { No. Of Event- } \\
\text { Creditor Obs. }\end{array}$ & Total & Mean & Median & Max & Min \\
\hline Bankrupt Companies & 509 & $27,197.0$ & 53.4 & 3.7 & $1,987.5$ & 0.0 \\
\hline Commercial Banks & 72 & 548.4 & 7.6 & 2.5 & 79.1 & 0.0 \\
\hline Other Financial Companies & 437 & $26,648.6$ & 61.0 & 4.0 & $1,987.5$ & 0.0 \\
\hline
\end{tabular}

Panel C. Claims made by publicly-listed creditors

\begin{tabular}{|c|c|c|c|c|c|c|}
\hline & $\begin{array}{l}\text { No. Of Event- } \\
\text { Creditor Obs. }\end{array}$ & Total & Mean & Median & Max & Min \\
\hline Bankrupt Companies & 242 & $11,216.2$ & 46.3 & 1.0 & $1,934.7$ & 0.0 \\
\hline Commercial Banks & 21 & 27.6 & 1.3 & 0.4 & 7.7 & 0.0 \\
\hline Other Financial Companies & 221 & $11,188.6$ & 50.6 & 1.1 & $1,934.7$ & 0.0 \\
\hline
\end{tabular}

Panel D. Claims as a fraction of assets of publicly-listed creditors

\begin{tabular}{|c|c|c|c|c|c|c|}
\hline & $\begin{array}{l}\text { No. Of Event- } \\
\text { Creditor Obs. }\end{array}$ & Mean & Median & Max & Min & $\%(<1.5 \%)$ \\
\hline Bankrupt Companies & 242 & 0.05 & 0.002 & 1.307 & 0.0 & 100.0 \\
\hline Commercial Banks & 21 & 0.13 & 0.002 & 1.307 & 0.0 & 100.0 \\
\hline Other Financial Companies & 221 & 0.04 & 0.002 & 1.269 & 0.0 & 100.0 \\
\hline Commercial Bank Creditors & 71 & 0.03 & 0.004 & 1.269 & 0.0 & 100.0 \\
\hline Other Creditors & 171 & 0.06 & 0.002 & 1.307 & 0.0 & 100.0 \\
\hline \multicolumn{7}{|c|}{ Panel E. Claims as a fraction of market value of equity of publicly-listed creditors } \\
\hline & $\begin{array}{l}\text { No. Of Event- } \\
\text { Creditor Obs. }\end{array}$ & Mean & Median & Max & Min & $\%(<15 \%)$ \\
\hline Bankrupt Companies & 242 & 0.24 & 0.012 & 12.300 & 0.0 & 100.0 \\
\hline Commercial Banks & 21 & 0.14 & 0.006 & 1.045 & 0.0 & 100.0 \\
\hline Other Financial Companies & 221 & 0.25 & 0.014 & 12.300 & 0.0 & 100.0 \\
\hline Commercial Bank Creditors & 71 & 0.32 & 0.040 & 12.300 & 0.0 & 100.0 \\
\hline Other Creditors & 171 & 0.20 & 0.006 & 5.535 & 0.0 & 100.0 \\
\hline \multicolumn{7}{|c|}{ Panel F. Debt owed per creditor across all bankruptcies } \\
\hline & $\begin{array}{l}\text { No. Of Event- } \\
\text { Creditor Obs. }\end{array}$ & Mean & Median & Max & Min & \\
\hline Total debt per creditor & 133 & 84.33 & 0.8 & $1,949.4$ & 0.0 & \\
\hline Total debt/assets per creditor & 133 & 0.09 & 0.008 & 1.307 & 0.0 & \\
\hline Total debt/equity per creditor & 133 & 0.44 & 0.019 & 12.300 & 0.0 & \\
\hline
\end{tabular}




\section{Table IV}

\section{Panel A: Counterparty Contagion and Creditor Stock Returns}

The table presents abnormal equity returns (AR) and cumulative abnormal returns (CAR) for the creditor portfolio (N=62) when a firm filed for Chapter 11 bankruptcy over the period 1981-2010 in our sample. The creditor portfolio return is constructed as a portfolio of equally-weighted equity returns of all publicly-listed unsecured creditors disclosed in the bankruptcy filing for each bankruptcy event. Then we average these returns across events. AR (CAR) is the market-adjusted cumulative abnormal returns (in percent) of the creditor portfolio, defined from the market model estimated over the period (-250, -50). The market return is proxied by the CRSP value-weighted equity returns. Statistical significance for ARs (CARs) is tested following MacKinlay (1997). The "\% $(<0) "$ entry indicates the percentage of observations with negative or zero values. The lower panel treats each creditor seperately

and CAR are averaged across creditors. The superscripts ***, **, and * indicate significance at $1 \%, 5 \%$ and $10 \%$ levels, respectively.

\begin{tabular}{|c|c|c|c|c|c|c|c|c|c|}
\hline \multicolumn{4}{|c|}{ Creditor Portfolio CAR (N=62) } & \multicolumn{3}{|c|}{ Financial Creditor Portfolio CAR $(\mathrm{N}=50)$} & \multicolumn{3}{|c|}{ Bankrutpcy After 2007 (N=34) } \\
\hline Day & Mean (\%) & T-stat. & $\%<0$ & Mean (\%) & T-stat. & $\%<0$ & Mean (\%) & T-stat. & $\%<0$ \\
\hline-5 & 0.33 & 1.52 & 46.8 & 0.52 & 1.52 & 50.0 & 0.44 & 1.27 & 44.1 \\
\hline-4 & -0.27 & -0.99 & 60.3 & -0.28 & -1.13 & 52.2 & -0.55 & -1.27 & 64.5 \\
\hline-3 & 0.02 & 0.10 & 49.2 & -0.01 & -0.01 & 57.1 & -0.02 & -0.04 & 44.1 \\
\hline-2 & -0.04 & -0.17 & 52.5 & 0.47 & 1.01 & 49.0 & 0.02 & 0.07 & 57.6 \\
\hline-1 & $-0.48 * * *$ & -2.62 & 61.7 & $-0.50 *$ & -1.68 & 59.2 & $-0.54^{*}$ & -1.87 & 63.6 \\
\hline 0 & -0.25 & -0.94 & 53.2 & $-0.91 * *$ & -2.09 & 56.0 & -0.33 & -0.77 & 50.0 \\
\hline 1 & -0.13 & -0.71 & 53.3 & 0.09 & 0.41 & 50.0 & -0.12 & -0.44 & 48.5 \\
\hline 2 & -0.23 & -1.18 & 60.7 & -0.29 & -0.95 & 68.0 & -0.24 & -0.73 & 66.7 \\
\hline 3 & -0.26 & -0.92 & 58.1 & -0.28 & -0.55 & 54.0 & -0.17 & -0.34 & 47.1 \\
\hline 4 & 0.11 & 0.36 & 48.3 & 0.10 & 0.19 & 52.1 & 0.24 & 0.49 & 42.4 \\
\hline 5 & -0.34 & -1.38 & 66.7 & $-0.94 * *$ & -2.25 & 73.9 & $-0.62 *$ & -1.72 & 71.0 \\
\hline 0,1 & -0.37 & -1.18 & 53.2 & $-0.82 *$ & -1.76 & 56.0 & -0.44 & -0.84 & 50.0 \\
\hline$-1,1$ & $-0.83 * *$ & -2.51 & 58.1 & $-1.31 * *$ & -2.33 & 56.0 & $-0.96 *$ & -1.84 & 50.0 \\
\hline$-2,2$ & $-1.09 * *$ & -2.16 & 64.5 & -1.14 & -1.41 & 58.0 & -1.17 & -1.41 & 64.7 \\
\hline$-5,5$ & -1.46 & -1.63 & 61.3 & $-1.92 * *$ & -2.07 & 70.0 & -1.75 & -1.15 & 58.8 \\
\hline
\end{tabular}




\section{Table IV}

\section{Panel B: Summary Statistics for Cross-Section Regression Variables $(\mathrm{N}=314)$}

The sample includes creditors for firms in Table IV, Panel A and for AHM, Lehman and AIG. Exposure is the measured either as creditor's claim over its total assets or over the market value of its equity. Bankruptcy size is total assets of the failed firm and creditor size is total assets of the creditor. Volatility is calculated using creditor equity returns during the 252 days preceding the event. Equity correlation uses equity returns of the failed firm and its creditor for 252 days preceding the event. Leverage is the total debt to the sum of total debt and market value of equity of the creditor, calculated as the average over the 4 quarters preceding the event. Derivatives claim is an indicator variable equal to 1 if the claim includes derivatives, and zero otherwise.

\begin{tabular}{l|ccccc}
\hline Variable & Mean & Std Dev & Min & Median & Max \\
\hline Exposure (\% assets ) & 0.93 & 6.06 & 0.00 & 0.03 & 90.40 \\
Exposure (\% equity) & 2.67 & 9.87 & 0.00 & 0.12 & 83.60 \\
Bankruptcy size (\$ b.) & 352.20 & 336.73 & 0.00 & 327.91 & 691.06 \\
Creditor size (\$ b.) & 326.35 & 604.39 & 0.03 & 38.26 & 3771.20 \\
Volatility & 3.03 & 1.68 & 0.76 & 2.71 & 12.36 \\
Equity correlation & 0.24 & 0.20 & -0.16 & 0.22 & 0.72 \\
Leverage & 0.68 & 0.27 & 0.00 & 0.79 & 0.99 \\
Claims are derivatives & 0.24 & 0.43 & 0.00 & 0.00 & 1.00 \\
Recession & 0.61 & 0.49 & 0.00 & 1.00 & 1.00 \\
\hline
\end{tabular}




\section{Table IV}

\section{Panel C: Regression Explaining Creditors' Abnormal Equity Returns}

The dependent variable, CAR, is the abnormal stock return from a market model for the creditor during the bankruptcy event window. The estimates are from an OLS regression. Reported in parentheses are t-statistics based on clustered standard errors, which are robust standard errors adjusted for clustering by bankruptcy events.

The superscripts ***, **, and * indicate significance at $1 \%, 5 \%$ and $10 \%$ levels, respectively.

\begin{tabular}{|c|c|c|c|c|c|c|}
\hline & \begin{tabular}{|l|} 
Expected \\
Sign \\
\end{tabular} & Model 1 & Model 2 & Model 3 & Model 4 & Model 5 \\
\hline & & Day 0 & Day $[-2,2]$ & Day 0 & Day 0 & Day 0 \\
\hline Constant & & $\begin{array}{c}1.71 \\
(1.01)\end{array}$ & $\begin{array}{c}5.24 \\
(1.36)\end{array}$ & $\begin{array}{c}2.62 \\
(1.36)\end{array}$ & $\begin{array}{c}1.37 \\
(0.88)\end{array}$ & $\begin{array}{c}2.17 \\
(1.14)\end{array}$ \\
\hline Exposure (\% of assets) & - & $\begin{array}{c}-0.08 * * * \\
(-6.25)\end{array}$ & $\begin{array}{c}-0.06 * * * \\
(-3.76)\end{array}$ & $\begin{array}{l}-0.08 * * * \\
(-7.32)\end{array}$ & & \\
\hline Exposure (\% of equity) & - & & & & $\begin{array}{c}-0.05 * * * \\
(-4.39)\end{array}$ & $\begin{array}{l}-0.05 * * * \\
(-6.30)\end{array}$ \\
\hline Size of bankrupt firm & - & $\begin{array}{c}0.09 \\
(0.74)\end{array}$ & $\begin{array}{c}-0.25 \\
(-1.18)\end{array}$ & $\begin{array}{c}0.11 \\
(0.58)\end{array}$ & $\begin{array}{c}0.08 \\
(0.71)\end{array}$ & $\begin{array}{c}0.11 \\
(0.60)\end{array}$ \\
\hline Size of creditor & $+/-$ & $\begin{array}{l}-0.10 \\
(-0.65)\end{array}$ & $\begin{array}{c}0.11 \\
(0.35)\end{array}$ & $\begin{array}{l}-0.18^{*} \\
(-1.90)\end{array}$ & $\begin{array}{c}-0.11 \\
(-0.75)\end{array}$ & $\begin{array}{c}-0.20^{* *} \\
(-2.21)\end{array}$ \\
\hline Derivatives claim & - & $\begin{array}{c}-1.34 * * * \\
(-4.84)\end{array}$ & $\begin{array}{c}-4.13 * * * \\
(-5.09)\end{array}$ & $\begin{array}{c}-1.17 * * * \\
(-4.78)\end{array}$ & $\begin{array}{c}-1.25^{* * *} \\
(-4.82)\end{array}$ & $\begin{array}{c}-1.10 * * * \\
(-5.04)\end{array}$ \\
\hline $\begin{array}{l}\text { Derivatives claim * Exposure (\% } \\
\text { assets or equity) }\end{array}$ & - & $\begin{array}{c}-0.40 * * * \\
(-9.20)\end{array}$ & $\begin{array}{l}-1.37 * * * \\
(-18.80)\end{array}$ & $\begin{array}{l}-0.43^{* * *} \\
(-15.60)\end{array}$ & $\begin{array}{c}-0.38 * * * \\
(-9.16)\end{array}$ & $\begin{array}{l}-0.41 * * * \\
(-13.84)\end{array}$ \\
\hline Leverage & - & $\begin{array}{l}-0.79 \\
(-0.84)\end{array}$ & $\begin{array}{l}-4.34 * * \\
(-2.40)\end{array}$ & $\begin{array}{c}-0.81 \\
(-0.93)\end{array}$ & $\begin{array}{l}-0.23 \\
(-0.25)\end{array}$ & $\begin{array}{l}-0.12 \\
(-0.16)\end{array}$ \\
\hline Volatility & - & $\begin{array}{c}-0.38 * * * \\
(-4.27)\end{array}$ & $\begin{array}{c}-1.11 * * * \\
(-3.27)\end{array}$ & $\begin{array}{c}-0.44 * * * \\
(-4.05)\end{array}$ & $\begin{array}{c}-0.30 * * * \\
(-2.74)\end{array}$ & $\begin{array}{l}-0.35^{* *} \\
(-2.41)\end{array}$ \\
\hline Equity correlation & $+/-$ & $\begin{array}{c}2.89 * * * \\
(2.96)\end{array}$ & $\begin{array}{c}1.13 \\
(0.80)\end{array}$ & $\begin{array}{c}2.92 * * * \\
(4.48)\end{array}$ & $\begin{array}{c}2.97 * * * \\
(2.90)\end{array}$ & $\begin{array}{c}2.88 * * * \\
(3.94)\end{array}$ \\
\hline Commercial bank creditor & + & $\begin{array}{c}0.92 \\
(1.38)\end{array}$ & $\begin{array}{c}3.43 \\
(1.24)\end{array}$ & $\begin{array}{c}1.63^{* * *} \\
(2.84)\end{array}$ & $\begin{array}{c}0.80 \\
(1.30)\end{array}$ & $\begin{array}{c}1.40^{* * *} \\
(2.68)\end{array}$ \\
\hline Recession & - & $\begin{array}{l}-1.14^{*} \\
(-1.71) \\
\end{array}$ & $\begin{array}{c}0.93 \\
(0.47) \\
\end{array}$ & $\begin{array}{l}-1.38^{*} \\
(-1.89) \\
\end{array}$ & $\begin{array}{l}-1.19 * \\
(-1.76) \\
\end{array}$ & $\begin{array}{l}-1.47^{*} \\
(-1.83) \\
\end{array}$ \\
\hline $\begin{array}{l}\text { R-square adj. (\%) } \\
\text { P-value for F-stat. } \\
\text { No. of Obs. (Clusters) } \\
\text { Sample }\end{array}$ & & $\begin{array}{c}8.68 \\
<.0001 \\
314(44) \\
\text { Full Sample }\end{array}$ & $\begin{array}{c}10.72 \\
<.0001 \\
314(44) \\
\text { Full Sample }\end{array}$ & $\begin{array}{c}9.91 \\
<.0001 \\
236(24) \\
2007-2010\end{array}$ & $\begin{array}{c}8.71 \\
<.0001 \\
314(44) \\
\text { Full Sample }\end{array}$ & $\begin{array}{c}9.90 \\
<.0001 \\
236(24) \\
2007-2010\end{array}$ \\
\hline
\end{tabular}




\section{Table V}

\section{Bankruptcy Filings and Information Contagion}

The table presents abnormal equity returns (AR) and cumulative abnormal returns (CAR) for the industry portfolio when a firm filed for Chapter 11 bankruptcy over the period 1981-2010 in our sample. The industry portfolio return is constructed as a portfolio of equally-weighted equity returns of all firms in the same 4digit SIC code for each bankruptcy event. The same state portfolio is consctructed as an equally-weighted portfolio with industry firms having the headquarter in the same state. The same business portfolio is an equally-weighted portfolio with industry firms in the real estate business for bankruptcy events associated with real estate problems. The subprime portfolio is an equally-weighted portfolio with industry firms involved in subprime home loan business for bankruptcy events associated with subprime home loan problems. Then we average these returns across events. AR (CAR) is the market-adjusted cumulative abnormal returns (in percent) of the industry portfolio, defined from the market model estimated over the period (-250, -50). The market return is proxied by the CRSP value-weighted equity returns. Statistical significance for ARs (CARs) is tested following MacKinlay (1997). The "\% $(<0)$ " entry indicates the percentage of observations with negative or zero values. The superscripts ***, **, and * indicate significance at $1 \%, 5 \%$ and $10 \%$ levels, respectively.

\begin{tabular}{|c|c|c|c|c|c|c|c|c|c|c|c|c|}
\hline \multirow[b]{3}{*}{ Day } & \multicolumn{3}{|c|}{ All Industry Portfolio } & \multicolumn{3}{|c|}{ Same State Portfolio } & \multicolumn{3}{|c|}{ Same Business Portfolio } & \multicolumn{3}{|c|}{ Same State and Same Business } \\
\hline & \multicolumn{3}{|c|}{$\mathrm{N}=142$} & \multicolumn{3}{|c|}{$\mathrm{N}=96$} & \multicolumn{3}{|c|}{$\mathrm{N}=89$} & \multicolumn{3}{|c|}{$\mathrm{N}=57$} \\
\hline & Mean (\%) & T-stat. & $\%<0$ & Mean (\%) & T-stat. & $\%<0$ & Mean (\%) & T-stat. & $\%<0$ & Mean (\%) & T-stat. & $\%<0$ \\
\hline-5 & -0.04 & -0.18 & 54.3 & -0.04 & -0.17 & 50.0 & -0.19 & -0.90 & 54.7 & -0.35 & -1.28 & 58.2 \\
\hline-4 & -0.43 & -1.84 & 49.3 & -0.44 & -1.47 & 56.7 & $-0.506^{*}$ & -1.75 & 52.9 & -0.28 & -0.66 & 54.7 \\
\hline-3 & -0.29 & -1.30 & 51.4 & 0.08 & 0.24 & 52.2 & 0.04 & 0.25 & 44.6 & 0.58 & 1.29 & 52.7 \\
\hline-2 & 0.38 & 1.60 & 42.6 & -0.46 & -1.22 & 57.0 & 0.19 & 0.97 & 41.9 & -0.12 & -0.56 & 55.4 \\
\hline-1 & 0.03 & 0.14 & 51.1 & -0.44 & -1.47 & 52.6 & 0.00 & -0.02 & 53.4 & 0.07 & 0.24 & 49.1 \\
\hline 0 & -0.15 & -0.66 & 54.9 & -0.29 & -1.05 & 57.3 & $-0.69 * * *$ & -2.63 & 59.6 & -0.35 & -0.97 & 56.1 \\
\hline 1 & 0.19 & 1.12 & 48.2 & -0.36 & -1.54 & 59.1 & 0.02 & 0.08 & 53.5 & -0.20 & -0.61 & 53.7 \\
\hline 2 & -0.27 & -1.14 & 53.0 & -0.08 & -0.20 & 48.9 & $-0.73^{* * *}$ & -3.04 & 59.5 & -0.65 & -1.48 & 51.0 \\
\hline 3 & -0.24 & -1.11 & 54.3 & 0.36 & 1.34 & 46.2 & -0.07 & -0.33 & 53.5 & 0.48 & 1.54 & 44.4 \\
\hline 4 & 0.02 & 0.06 & 51.8 & -0.35 & -1.60 & 60.2 & $-0.55 * * *$ & -2.68 & 64.2 & $-0.72 * * *$ & -2.84 & 58.8 \\
\hline 5 & 0.38 & 1.76 & 40.3 & 0.04 & 0.16 & 48.9 & -0.07 & -0.31 & 48.2 & -0.04 & -0.14 & 50.9 \\
\hline 0,1 & 0.04 & 0.13 & 45.1 & $-0.64^{*}$ & -1.67 & 56.3 & $-0.67 * *$ & -2.14 & 57.3 & -0.54 & -1.00 & 54.4 \\
\hline$-1,1$ & 0.07 & 0.19 & 44.4 & $-1.07 * *$ & -2.35 & 60.4 & $-0.67^{*}$ & -1.89 & 58.4 & -0.47 & -0.79 & 47.4 \\
\hline$-2,2$ & 0.18 & 0.37 & 43.7 & $-1.59 * *$ & -2.35 & 54.2 & $-1.13^{* *}$ & -2.37 & 53.9 & -1.15 & -1.47 & 54.4 \\
\hline$-5,5$ & -0.41 & -0.63 & 53.5 & $-1.91 * *$ & -2.06 & 58.3 & $-2.39 * * *$ & -2.85 & 53.9 & -1.41 & -1.54 & 52.6 \\
\hline
\end{tabular}




\section{Table VI}

\section{Distress Days and Information Contagion}

The table presents abnormal equity returns (AR) and cumulative abnormal returns (CAR) for the industry portfolio when a distressed firm experienced a single-day large price decline over the period 1982-2010 in our sample. The industry portfolio return is constructed as a portfolio of equally-weighted equity returns of all firms in the same 4-digit SIC code for each distress event. The same state portfolio is constructed as an equally-weighted portfolio with industry firms having headquarter in the same state. The same business portfolio is an equally-weighted portfolio with industry firms in the real estate business for distress events associated with real estate problems. The subprime portfolio is an equally-weighted portfolio with industry firms involved in subprime home loan business for distress events associated with subprime home loan problems. Then we average these returns across events. AR (CAR) is the market-adjusted cumulative abnormal returns (in percent) of the industry portfolio, defined from the market model estimated over the period $(-250,-50)$. The market return is proxied by the CRSP value-weighted equity returns. Statistical significance for ARs (CARs) is tested following MacKinlay (1997). The "\% $(<0) "$ entry indicates the percentage of observations with negative or zero values.

The superscripts $* * *, * *$, and $*$ indicate significance at $1 \%, 5 \%$ and $10 \%$ levels, respectively.

\begin{tabular}{|c|c|c|c|c|c|c|c|c|c|c|c|c|}
\hline \multirow[b]{3}{*}{ Day } & \multicolumn{2}{|c|}{$\begin{array}{c}\text { All Industry } \\
\text { Portfolio } \\
\end{array}$} & \multicolumn{2}{|c|}{$\begin{array}{c}\text { Same State } \\
\text { Portfolio } \\
\end{array}$} & \multicolumn{2}{|c|}{$\begin{array}{c}\text { Same Business } \\
\text { Portfolio } \\
\end{array}$} & \multicolumn{2}{|c|}{$\begin{array}{c}\text { Same State and } \\
\text { Same Business } \\
\text { Portfolio } \\
\end{array}$} & \multicolumn{2}{|c|}{$\begin{array}{c}2007-2010 \\
\text { Same Business } \\
\text { Portfolio } \\
\end{array}$} & \multicolumn{2}{|c|}{$\begin{array}{c}\text { 2007-2010 Same } \\
\text { State and Same } \\
\text { Business Portfolio }\end{array}$} \\
\hline & \multicolumn{2}{|c|}{$\mathrm{N}=149$} & \multicolumn{2}{|c|}{$\mathrm{N}=84$} & \multicolumn{2}{|c|}{$\mathrm{N}=82$} & \multicolumn{2}{|c|}{$\mathrm{N}=\mathbf{3 8}$} & \multicolumn{2}{|c|}{$\mathrm{N}=44$} & \multicolumn{2}{|c|}{$\mathrm{N}=\mathbf{2 0}$} \\
\hline & $\begin{array}{l}\text { Mean } \\
(\%)\end{array}$ & $\%<0$ & $\begin{array}{c}\text { Mean } \\
(\%)\end{array}$ & $\%<0$ & $\begin{array}{l}\text { Mean } \\
(\%)\end{array}$ & $\%<0$ & $\begin{array}{l}\text { Mean } \\
(\%)\end{array}$ & $\%<0$ & $\begin{array}{c}\text { Mean } \\
(\%)\end{array}$ & $\%<0$ & Mean (\%) & $\%<0$ \\
\hline-5 & 0.00 & 47.9 & 0.29 & 51.3 & 0.47 & 48.7 & 0.27 & 54.3 & 0.79 & 47.6 & 0.42 & 55.6 \\
\hline-4 & -0.15 & 53.1 & 0.32 & 53.7 & 0.24 & 56.3 & -0.03 & 67.6 & 0.56 & 55.8 & 0.82 & 52.6 \\
\hline-3 & 0.09 & 51.8 & 0.21 & 48.1 & 0.42 & 46.8 & 0.11 & 44.4 & 0.51 & 42.9 & 0.28 & 38.9 \\
\hline-2 & -0.12 & 60.3 & $-0.56^{* *}$ & 62.2 & -0.41 & 65.8 & -0.40 & 70.3 & -0.35 & 65.1 & -0.76 & 73.7 \\
\hline-1 & -0.27 & 54.2 & -0.27 & 58.5 & -0.36 & 52.5 & -0.15 & 57.9 & $-1.24 *$ & 55.8 & -0.08 & 50.0 \\
\hline 0 & $-0.63 * * *$ & 66.4 & $-1.37 * * *$ & 69.0 & $-2.04 * * *$ & 76.8 & $-2.84 * *$ & 73.7 & $-3.00 * * *$ & 79.5 & $-4.61 *$ & 65.0 \\
\hline 1 & 0.24 & 54.4 & 0.05 & 57.8 & $0.99 * *$ & 56.1 & -0.03 & 60.5 & $1.49 *$ & 50.0 & 0.39 & 60.0 \\
\hline 2 & $-0.40 * * *$ & 61.8 & $-0.78^{* *}$ & 55.6 & $-0.78^{*}$ & 61.3 & $-1.11 *$ & 64.9 & -1.18 & 55.8 & -1.41 & 57.9 \\
\hline 3 & -0.09 & 49.7 & -0.25 & 56.1 & 0.13 & 50.0 & -0.61 & 62.2 & -0.07 & 52.4 & -0.85 & 73.7 \\
\hline 4 & 0.14 & 50.0 & -0.50 & 59.8 & 0.57 & 45.0 & -0.38 & 62.2 & 0.89 & 42.9 & -1.38 & 68.4 \\
\hline 5 & -0.04 & 50.4 & $-0.74^{* *}$ & 66.7 & -0.07 & 60.3 & $-1.67 * *$ & 74.3 & -0.27 & 61.9 & $-2.91 * *$ & 78.9 \\
\hline 0,1 & $-0.39 * *$ & 62.4 & $-1.30 * *$ & 62.4 & $-1.05^{* *}$ & 68.3 & $-2.86 * *$ & 63.2 & $-1.51^{*}$ & 70.5 & $-4.22 *$ & 60.0 \\
\hline$-1,1$ & $-0.65^{* *}$ & 57.0 & $-1.56 * * *$ & 57.6 & $-1.41^{*}$ & 59.8 & $-3.01 * *$ & 52.6 & $-2.72^{* *}$ & 61.4 & -4.30 & 50.0 \\
\hline$-2,2$ & $-1.15^{* * *}$ & 65.8 & $-2.85 * * *$ & 69.4 & $-2.56 * * *$ & 70.7 & $-4.48 * * *$ & 68.4 & $-4.22 * * *$ & 72.7 & $-6.36^{* *}$ & 70.0 \\
\hline$-5,5$ & $-1.20 * *$ & 69.8 & $-3.46 * * *$ & 69.4 & -0.86 & 68.3 & $-6.67 * * *$ & 73.7 & -1.91 & 70.5 & $-9.84^{* *}$ & 75.0 \\
\hline
\end{tabular}


Table VII

Descriptive Cross-Sectional Statistics

\begin{tabular}{|c|c|c|c|c|c|}
\hline \multicolumn{6}{|c|}{ Panel A: Bankruptcy Event Sample Partioned by State $(\mathrm{N}=193)$} \\
\hline Variable & Mean & Std Dev & Min & Median & Max \\
\hline Same_dummy & 0.37 & 0.48 & 0.00 & 0.00 & 1.00 \\
\hline Bankrupt/distressed firm size (\$ b.) & 16 & 77 & 0 & 2 & 691 \\
\hline Equity correlation & 0.09 & 0.16 & -0.20 & 0.04 & 0.71 \\
\hline Rival volatility & 2.08 & 1.83 & 0.00 & 1.73 & 15.35 \\
\hline Rival rating & 14.56 & 2.38 & 5.00 & 14.40 & 21.00 \\
\hline Industry Herfindahl index & 0.13 & 0.14 & 0.02 & 0.09 & 0.79 \\
\hline Recession & 0.35 & 0.48 & 0.00 & 0.00 & 1.00 \\
\hline \multicolumn{6}{|c|}{ Panel B: Bankruptcy Event Sample Partioned by Business (N=110) } \\
\hline Variable & Mean & Std Dev & Min & Median & Max \\
\hline Same_dummy & 0.72 & 0.45 & 0.00 & 1.00 & 1.00 \\
\hline Bankrupt/distressed firm size (\$ b.) & 16 & 72 & 0 & 2 & 691 \\
\hline Equity correlation & 0.11 & 0.17 & -0.11 & 0.06 & 0.71 \\
\hline Rival volatility & 2.14 & 1.56 & 0.00 & 1.83 & 7.82 \\
\hline Rival rating & 14.21 & 2.33 & 7.00 & 14.00 & 21.00 \\
\hline Industry Herfindahl index & 0.12 & 0.14 & 0.02 & 0.04 & 0.79 \\
\hline Recession & 0.16 & 0.37 & 0.00 & 0.00 & 1.00 \\
\hline \multicolumn{6}{|c|}{ Panel C: Distress Event Sample Partioned by State $(\mathrm{N}=233)$} \\
\hline Variable & Mean & Std Dev & Min & Median & Max \\
\hline Same_dummy & 0.34 & 0.47 & 0.00 & 0.00 & 1.00 \\
\hline Bankrupt/distressed firm size (\$ b.) & 71 & 200 & 1 & 12 & 1707 \\
\hline Equity correlation & 0.38 & 0.24 & -0.10 & 0.41 & 0.87 \\
\hline Rival volatility & 1.63 & 1.18 & 0.00 & 1.19 & 6.27 \\
\hline Rival rating & 14.40 & 2.21 & 6.00 & 14.47 & 23.00 \\
\hline Industry Herfindahl index & 0.15 & 0.17 & 0.01 & 0.07 & 0.79 \\
\hline Recession & 0.29 & 0.45 & 0.00 & 0.00 & 1.00 \\
\hline Distress day return & -0.35 & 0.21 & -0.90 & -0.33 & -0.06 \\
\hline \multicolumn{6}{|c|}{ Panel D: Distress Event Sample Partioned by Business $(\mathrm{N}=118)$} \\
\hline Variable & Mean & Std Dev & Min & Median & Max \\
\hline $\begin{array}{l}\text { Same_dummy } \\
\end{array}$ & 0.69 & 0.46 & 0.00 & 1.00 & 1.00 \\
\hline Bankrupt/distressed firm size (\$ b.) & 135 & 309 & 3 & 12 & 1707 \\
\hline Equity correlation & 0.41 & 0.24 & -0.12 & 0.46 & 0.88 \\
\hline Rival volatility & 2.12 & 1.78 & 0.00 & 1.70 & 9.84 \\
\hline Rival rating & 14.76 & 2.20 & 10.00 & 14.52 & 21.00 \\
\hline Industry Herfindahl index & 0.14 & 0.16 & 0.01 & 0.09 & 0.79 \\
\hline Recession & 0.45 & 0.50 & 0.00 & 0.00 & 1.00 \\
\hline Distress day return & -0.41 & 0.23 & -0.90 & -0.38 & -0.08 \\
\hline \multicolumn{6}{|c|}{$\begin{array}{l}\text { Variable definitions: Same_dummy is a dummy variable that is equal to } 1 \text { if the bankrupt or distressed } \\
\text { firm (the 'event' firm) and the industry portfolio are in the same state, conduct real estate business, or } \\
\text { both in the same state and conduct real estate business, and } 0 \text { otherwise, Bankrupt/distressed firm size is } \\
\text { total assets of the 'event' firm and it natural logarithm is used in the regression in Table } 8 \text {, Equity } \\
\text { correlation is the correlation of equity returns between the 'event' firm and the industry portfolios for } \\
252 \text { days preceding the event, Rival volatility is the equity return volatility of the industry portfolios for } \\
\text { the } 252 \text { days preceding the event, Rival rating is the average bond rating of industry portfolio, where } \\
\text { S\&P ratings are obtained from Compustat and assigned a number on a cardinal scale, ranging from } 1 \text { for } \\
\text { AAA, } 2 \text { for AA+, to } 21 \text { for C, Industry Herfindahl index is computed as the sum of the squared fractions } \\
\text { of each individual firm sales over total sales of the industry portfolio, Recession is a dummy variable to } \\
\text { proxy for the macro economic conditions, Distress day return is the equity return of the distressed firm } \\
\text { on the 'event' day. }\end{array}$} \\
\hline
\end{tabular}




\section{Table VIII}

\section{Cross-Sectional Analysis of Industry Portfolio' Abnormal Equity Returns}

The dependent variable, CAR, is defined as the cumulated abnormal stock returns for the industry competitors for the $[-2,2]$ daily interval around the 'event' day from a market model; other variables are defined in Table VII. The estimates are from an OLS regression. Reported in parentheses are t-statistics based on clustered standard errors, which are robust standard errors adjusted for clustering by the 'event' firms. The numbers in parentheses are tstatistics.

The superscripts $* * *, * *$, and $*$ indicate significance at $1 \%, 5 \%$ and $10 \%$ levels, respectively.

\begin{tabular}{|c|c|c|c|c|c|c|c|}
\hline & & \multicolumn{3}{|c|}{ Bankruptcy Sample } & \multicolumn{3}{|c|}{ Distress Sample } \\
\hline & $\begin{array}{c}\text { Expecte } \\
\text { d Sign }\end{array}$ & Model 1 & Model 2 & Model 3 & Model 1 & Model 2 & Model 3 \\
\hline Constant & & $\begin{array}{c}3.17 \\
(1.02)\end{array}$ & $\begin{array}{c}4.34 \\
(1.11)\end{array}$ & $\begin{array}{c}1.53 \\
(0.50)\end{array}$ & $\begin{array}{c}2.15 \\
(0.79)\end{array}$ & $\begin{array}{c}1.85 \\
(0.43)\end{array}$ & $\begin{array}{c}2.39 \\
(0.61)\end{array}$ \\
\hline Same_state & - & $\begin{array}{c}-2.13 * * * \\
(-3.41)\end{array}$ & & & $\begin{array}{c}-1.85 * * * \\
(-2.66)\end{array}$ & & \\
\hline Same_business & - & & $\begin{array}{c}-1.36 * * \\
(-2.24)\end{array}$ & & & $\begin{array}{c}-2.38^{* *} \\
(-2.26)\end{array}$ & \\
\hline Same_state_business & - & & & $\begin{array}{c}-1.94 * * * \\
(-2.72)\end{array}$ & & & $\begin{array}{c}-3.16^{* *} \\
(-2.14)\end{array}$ \\
\hline Equity correlation & - & $\begin{array}{l}-4.95^{*} \\
(-1.65)\end{array}$ & $\begin{array}{c}0.51 \\
(0.16)\end{array}$ & $\begin{array}{l}-6.98^{*} \\
(-1.92)\end{array}$ & $\begin{array}{c}-2.73 * * \\
(-2.14)\end{array}$ & $\begin{array}{c}-5.19 * * \\
(-2.06)\end{array}$ & $\begin{array}{c}-3.45 * * \\
(-2.09)\end{array}$ \\
\hline Bankrupt/distressed firm size & $+/-$ & $\begin{array}{c}0.18 \\
(1.02)\end{array}$ & $\begin{array}{c}-0.24 \\
(-0.99)\end{array}$ & $\begin{array}{c}0.21 \\
(1.25)\end{array}$ & $\begin{array}{c}0.17 \\
(0.87)\end{array}$ & $\begin{array}{c}0.21 \\
(0.78)\end{array}$ & $\begin{array}{c}0.30 \\
(1.27)\end{array}$ \\
\hline Rival volatility & - & $\begin{array}{c}0.04 \\
(0.11)\end{array}$ & $\begin{array}{l}-0.20 \\
(-0.57)\end{array}$ & $\begin{array}{c}0.19 \\
(0.61)\end{array}$ & $\begin{array}{c}0.30 \\
(0.57)\end{array}$ & $\begin{array}{l}-0.48 \\
(-0.78)\end{array}$ & $\begin{array}{c}-0.55 \\
(-0.51)\end{array}$ \\
\hline Rival rating & - & $\begin{array}{c}-0.24 \\
(-1.33)\end{array}$ & $\begin{array}{c}-0.07 \\
(-0.28)\end{array}$ & $\begin{array}{c}-0.15 \\
(-0.78)\end{array}$ & $\begin{array}{l}-0.30 * \\
(-1.65)\end{array}$ & $\begin{array}{c}0.02 \\
(0.08)\end{array}$ & $\begin{array}{c}-0.28 \\
(-1.05)\end{array}$ \\
\hline Industry Herfindahl index & + & $\begin{array}{c}7.30 * * \\
(2.28)\end{array}$ & $\begin{array}{l}-4.48 \\
(-0.85)\end{array}$ & $\begin{array}{c}7.34^{* *} \\
(2.33)\end{array}$ & $\begin{array}{l}-0.60 \\
(-0.26)\end{array}$ & $\begin{array}{c}-5.36 \\
(-1.38)\end{array}$ & $\begin{array}{c}-2.35 \\
(-0.79)\end{array}$ \\
\hline Recession & - & $\begin{array}{c}-2.09 * * * \\
(-2.74)\end{array}$ & $\begin{array}{l}-1.05 \\
(-0.74)\end{array}$ & $\begin{array}{c}-2.20 * * * \\
(-2.82)\end{array}$ & $\begin{array}{c}-0.37 \\
(-0.38)\end{array}$ & $\begin{array}{c}-1.21 \\
(-1.15)\end{array}$ & $\begin{array}{c}0.43 \\
(0.25)\end{array}$ \\
\hline $\begin{array}{l}\text { R-square adj. (\%) } \\
\text { P-value for F-stat. } \\
\text { No. of Obs. }\end{array}$ & & $\begin{array}{c}9.60 \\
0.0025 \\
193 \\
\end{array}$ & $\begin{array}{c}5.78 \\
0.0684 \\
110 \\
\end{array}$ & $\begin{array}{c}11.13 \\
0.0213 \\
170 \\
\end{array}$ & $\begin{array}{c}5.16 \\
0.0313 \\
233 \\
\end{array}$ & $\begin{array}{c}9.73 \\
0.0470 \\
118 \\
\end{array}$ & $\begin{array}{c}9.65 \\
0.0508 \\
188 \\
\end{array}$ \\
\hline
\end{tabular}


Table IX

Panel A: Exposures to Lehman Brothers Holding Inc. (in \$ millions)

\begin{tabular}{|c|c|c|c|c|c|c|c|}
\hline & $\begin{array}{l}\text { No. of } \\
\text { claims }\end{array}$ & Mean & Median & Max & Min & Total & \\
\hline All claims above $\$ 1$ million & 6,560 & 81.5 & 4.8 & $73,162.3$ & 1.0 & $534,359.0$ & \\
\hline Claims made by trustees & 678 & 510.8 & 4.9 & $73,162.3$ & 1.0 & $346,288.2$ & \\
\hline \multirow[t]{2}{*}{ Other claims } & 5,882 & 32.0 & 4.8 & $19,058.0$ & 1.0 & $188,071.0$ & \\
\hline & No. & Mean & Median & Max & Min & Total & \\
\hline Claims owed to public creditors: & 163 & 347.1 & 19.3 & 15800.0 & 0.5 & 54147.1 & \\
\hline \multicolumn{8}{|l|}{ By type of creditor } \\
\hline $\begin{array}{l}\text { Nonfinancial creditors } \\
\text { Financial creditors }\end{array}$ & $\begin{array}{c}53 \\
110\end{array}$ & $\begin{array}{c}64.9 \\
492.3\end{array}$ & $\begin{array}{c}6.4 \\
34.0\end{array}$ & $\begin{array}{c}920.0 \\
15,800.0\end{array}$ & $\begin{array}{l}0.7 \\
0.5\end{array}$ & $\begin{array}{c}3,439.3 \\
50,707.8\end{array}$ & \\
\hline \multicolumn{8}{|l|}{ By type of claim } \\
\hline Derivatives & 38 & 162.9 & 7.9 & $2,500.0$ & 1.0 & $6,189.5$ & \\
\hline Equity & 5 & 11.8 & 5.8 & 32.0 & 1.0 & 59.2 & \\
\hline Unsecured debt & 80 & 79.5 & 15.5 & 920.0 & 0.5 & $6,356.4$ & \\
\hline \multirow[t]{2}{*}{ Bonds and derivatives } & 40 & $1,258.9$ & 127.0 & $15,800.0$ & 1.2 & $41,542.0$ & \\
\hline & No. & Mean & Median & Max & Min & $\%(<1.5 \%)$ & $\mathbf{t}$ \\
\hline \multicolumn{8}{|c|}{ Claim/assets (\%) for public creditors: } \\
\hline \multicolumn{8}{|l|}{ By type of creditor } \\
\hline Nonfinancial creditors & 53 & 4.2 & 0.1 & 90.4 & 0.0 & 75.5 & 1.4 \\
\hline Financial creditors & 110 & 0.5 & 0.2 & 13.8 & 0.0 & $93.2^{* * *}$ & 5.9 \\
\hline \multicolumn{8}{|l|}{ By type of claim } \\
\hline Derivatives & 38 & 1.3 & 0.1 & 13.8 & 0.0 & 81.6 & 0.4 \\
\hline Equity & 5 & 0.6 & 0.2 & 2.0 & 0.1 & $80 * *$ & 2.5 \\
\hline Unsecured debt & 80 & 2.7 & 0.2 & 90.4 & 0.0 & 86.3 & 0.9 \\
\hline \multirow[t]{2}{*}{ Bonds and derivatives } & 40 & 0.2 & 0.1 & 1.8 & 0.0 & $97 * * *$ & 21.9 \\
\hline & No. & Mean & Median & Max & Min & $\%(<15 \%)$ & $\mathbf{t}$ \\
\hline \multicolumn{8}{|c|}{ Claim/equity (\%) for public creditors: } \\
\hline & 163 & 4.8 & 0.9 & 83.6 & 0.0 & $93.6^{* * *}$ & 9.7 \\
\hline \multicolumn{8}{|l|}{ By type of creditor } \\
\hline Nonfinancial creditors & 53 & 5.1 & 0.1 & 83.6 & 0.0 & $92.5 * * *$ & 5.0 \\
\hline Financial creditors & 110 & 4.7 & 1.1 & 75.7 & 0.0 & $94.2^{* * *}$ & 8.5 \\
\hline \multicolumn{8}{|l|}{ By type of claim } \\
\hline Derivatives & 38 & 4.4 & 0.2 & 60.8 & 0.0 & $92.1^{* * *}$ & 5.5 \\
\hline Equity & 5 & 1.0 & 0.4 & 3.0 & 0.1 & $100 * * *$ & 26.4 \\
\hline Unsecured debt & 80 & 5.0 & 0.9 & 83.6 & 0.0 & $93.8^{* * *}$ & 6.4 \\
\hline Bonds and derivatives & 40 & 5.3 & 1.0 & 75.7 & 0.0 & $93.9 * * *$ & 4.2 \\
\hline
\end{tabular}




\section{Table IX}

Panel B: Exposures to American Home Mortgage Corp. (in \$ millions)

\begin{tabular}{|c|c|c|c|c|c|c|}
\hline & $\begin{array}{l}\text { No. of } \\
\text { claims }\end{array}$ & Mean & Median & Max & Min & Total \\
\hline All claims above $\$ 1$ million & 75 & 35.9 & 11.6 & 224.3 & 1.1 & $2,692.1$ \\
\hline Claims by financial companies & 62 & 40.9 & 14.4 & 224.3 & 1.1 & $2,533.8$ \\
\hline Claims not made by trustees & 45 & 39.9 & 11.6 & 224.3 & 1.1 & $1,795.0$ \\
\hline Claims by public financial companies & 34 & 31.2 & 7.1 & 224.3 & 1.1 & $1,059.9$ \\
\hline \multicolumn{7}{|l|}{ By type of claim } \\
\hline Loan Repurchase Request & 26 & 37.7 & 10.2 & 224.3 & 1.2 & 980.9 \\
\hline Master Repurchase Agreement & 3 & 14.8 & 5.2 & 37.6 & 1.5 & 44.4 \\
\hline Derivative & 4 & 8.4 & 4.7 & 20.1 & 4.0 & 33.5 \\
\hline Lease & 1 & 1.1 & 1.1 & 1.1 & 1.1 & 1.1 \\
\hline Claims/total assets (\%) by industry & $\begin{array}{c}\text { No. of } \\
\text { claimants }\end{array}$ & Mean & Median & Max & Min & \\
\hline 6020 & 7 & 0.0047 & 0.0051 & 0.0103 & 0.0003 & \\
\hline 6035 & 2 & 0.0136 & 0.0136 & 0.0266 & 0.0006 & \\
\hline 6162 & 1 & 0.1155 & 0.1155 & 0.1155 & 0.1155 & \\
\hline 6199 & 1 & 0.0039 & 0.0039 & 0.0039 & 0.0039 & \\
\hline 6211 & 6 & 0.0013 & 0.0009 & 0.0035 & 0.0001 & \\
\hline 6282 & 1 & 0.0001 & 0.0001 & 0.0001 & 0.0001 & \\
\hline 6351 & 2 & 0.2860 & 0.2860 & 0.5124 & 0.0597 & \\
\hline 6798 & 2 & 0.0503 & 0.0503 & 0.0754 & 0.0253 & \\
\hline All & 22 & 0.0391 & 0.0037 & 0.5124 & 0.0001 & \\
\hline Claims/market value of equity (\%) by industry & $\begin{array}{c}\text { No. of } \\
\text { claimants }\end{array}$ & Mean & Median & Max & Min & \\
\hline 6020 & 7 & 0.0781 & 0.0471 & 0.2031 & 0.0363 & \\
\hline 6035 & 2 & 0.1988 & 0.1988 & 0.3924 & 0.0052 & \\
\hline 6162 & 1 & 1.2072 & 1.2072 & 1.2072 & 1.2072 & \\
\hline 6199 & 1 & 0.0336 & 0.0336 & 0.0336 & 0.0336 & \\
\hline 6211 & 6 & 0.0165 & 0.0173 & 0.0289 & 0.0016 & \\
\hline 6282 & 1 & 0.0022 & 0.0022 & 0.0022 & 0.0022 & \\
\hline 6351 & 2 & 1.4484 & 1.4484 & 2.8083 & 0.0884 & \\
\hline 6798 & 2 & 0.8330 & 0.8330 & 1.6281 & 0.0379 & \\
\hline All & 22 & 0.3346 & 0.0371 & 2.8083 & 0.0016 & \\
\hline
\end{tabular}




\section{Table IX}

Panel C: Exposures to American International Group (in \$ millions)

\begin{tabular}{|c|c|c|c|c|c|c|}
\hline & No. of claims & Mean & Median & Max & Min & Total \\
\hline Payments to financial firm creditors: & 51 & 1,731 & 900 & 7,000 & 0 & 88,300 \\
\hline CDS & 20 & 915 & 500 & 4,100 & 200 & 18,300 \\
\hline Maiden Lane III (CDO) & 15 & 1,787 & 900 & 6,900 & 0 & 26,800 \\
\hline Securities lending & 16 & 2,700 & 2,050 & 7,000 & 200 & 43,200 \\
\hline Payments to public financial companies & 39 & 2,054 & 1,000 & 7,000 & 0 & 80,100 \\
\hline CDS & 15 & 1,020 & 400 & 4,100 & 200 & 15,300 \\
\hline Maiden Lane III (CDO) & 11 & 2,200 & 900 & 6,900 & 0 & 24,200 \\
\hline Securities lending & 13 & 3,123 & 2,300 & 7,000 & 400 & 40,600 \\
\hline Payments by industry: & $\begin{array}{l}\text { No. of } \\
\text { claimants }\end{array}$ & Mean & Median & Max & Min & Total \\
\hline 6020 & 12 & 4167 & 2500 & 11900 & 200 & 50,000 \\
\hline 6199 & 1 & 2300 & 2300 & 2300 & 2300 & 2,300 \\
\hline 6211 & 4 & 5325 & 4000 & 12900 & 400 & 21,300 \\
\hline 6282 & 1 & 5000 & 5000 & 5000 & 5000 & 5,000 \\
\hline 6311 & 1 & 1500 & 1500 & 1500 & 1500 & 1,500 \\
\hline All & 19 & 4216 & 2300 & 12900 & 200 & 80,100 \\
\hline Payments/ total assets (\%) by industry & $\begin{array}{l}\text { No. of } \\
\text { claimants }\end{array}$ & Mean & Median & Max & Min & \\
\hline 6020 & 12 & 0.21 & 0.18 & 0.70 & 0.02 & \\
\hline 6199 & 1 & 0.11 & 0.11 & 0.11 & 0.11 & \\
\hline 6211 & 4 & 0.51 & 0.41 & 1.19 & 0.03 & \\
\hline 6282 & 1 & 0.24 & 0.24 & 0.24 & 0.24 & \\
\hline 6311 & 1 & 0.07 & 0.07 & 0.07 & 0.07 & \\
\hline All & 19 & 0.26 & 0.17 & 1.19 & 0.02 & \\
\hline $\begin{array}{l}\text { Payments / market value of equity (\%) } \\
\text { by industry }\end{array}$ & $\begin{array}{c}\text { No. of } \\
\text { claimants }\end{array}$ & Mean & Median & Max & Min & \\
\hline 6020 & 12 & 9.56 & 4.71 & 27.36 & 0.26 & \\
\hline 6199 & 1 & 2.52 & 2.52 & 2.52 & 2.52 & \\
\hline 6211 & 4 & 10.91 & 10.49 & 21.81 & 0.86 & \\
\hline 6282 & 1 & 8.55 & 8.55 & 8.55 & 8.55 & \\
\hline 6311 & 1 & 2.35 & 2.35 & 2.35 & 2.35 & \\
\hline All & 19 & 8.98 & 4.52 & 27.36 & 0.26 & \\
\hline
\end{tabular}




\section{Table X}

\section{Panel A: Contagion Effect of Lehman's Distress on Unsecured Creditor's Stock Prices}

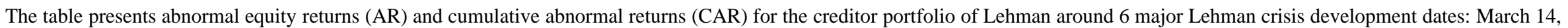

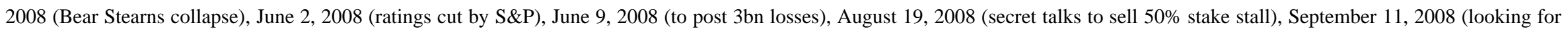

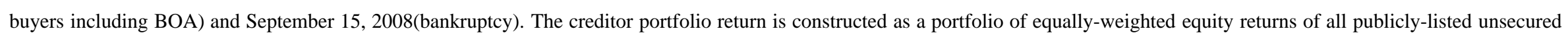

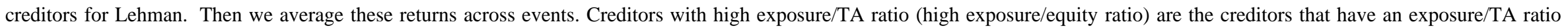

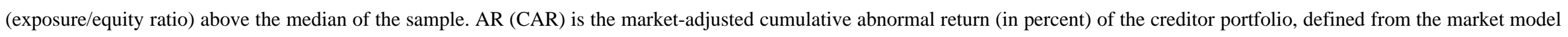

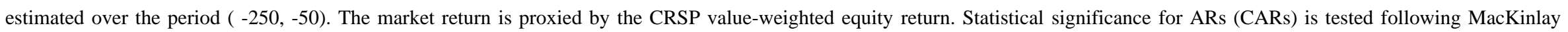

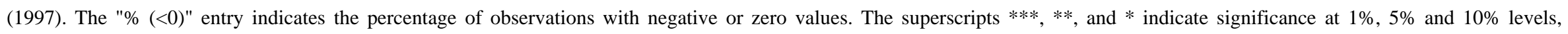
respectively.

\begin{tabular}{|c|c|c|c|c|c|c|c|c|c|c|c|c|}
\hline \multirow[b]{2}{*}{ Day } & \multicolumn{3}{|c|}{ All Creditors ( $N=163$ ) } & \multicolumn{3}{|c|}{ Financial Creditors $(\mathrm{N}=106)$} & \multicolumn{3}{|c|}{$\begin{array}{l}\text { Creditors with High Exposure/TA Ratio } \\
\qquad(\mathrm{N}=\mathbf{8 1})\end{array}$} & \multicolumn{3}{|c|}{$\begin{array}{l}\text { Creditors with High Exposure/Equity Ratio } \\
\qquad(\mathrm{N}=\mathbf{8 1})\end{array}$} \\
\hline & Mean (\%) & T-stat. & $\%<0$ & Mean (\%) & T-stat. & $\%<0$ & Mean (\%) & T-statistic & $\%(<0)$ & Mean (\%) & T-statistic & $\%(<0)$ \\
\hline-2 & -0.16 & -0.56 & 50.0 & -0.08 & -0.21 & 50.0 & -0.26 & -0.58 & 50.0 & -0.30 & -0.66 & 50.0 \\
\hline-1 & $-0.35 * *$ & -1.95 & 66.7 & $-0.73 * * *$ & -2.83 & 83.3 & $-0.63^{*}$ & -1.68 & 83.3 & $-0.71 *$ & -1.90 & 83.3 \\
\hline 0 & $-0.77 * * *$ & -4.85 & 100.0 & $-0.98 * * *$ & -4.47 & 100.0 & $-0.94 * * *$ & -3.48 & 100.0 & $-1.09 * * *$ & -3.31 & 100.0 \\
\hline 1 & $-0.47 *$ & -1.70 & 66.7 & -0.47 & -1.49 & 66.7 & $-0.93^{* *}$ & -2.21 & 66.7 & $-0.89 * *$ & -1.95 & 66.7 \\
\hline 2 & -0.40 & -1.36 & 83.3 & -0.46 & -0.94 & 83.3 & $-0.56^{*}$ & -1.67 & 83.3 & $-0.88 * *$ & -1.96 & 83.3 \\
\hline 0,1 & $-1.24 * * *$ & -3.33 & 83.3 & $-1.45 * * *$ & -3.13 & 83.3 & $-1.87 * * *$ & -3.17 & 83.3 & $-1.97 * * *$ & -2.77 & 83.3 \\
\hline$-1,1$ & $-1.59 * * *$ & -3.77 & 100.0 & $-2.18 * * *$ & -3.67 & 100.0 & $-2.50 * * *$ & -2.95 & 100.0 & $-2.68 * * *$ & -2.78 & 100.0 \\
\hline$-2,2$ & $-2.16^{* * *}$ & -2.94 & 83.3 & $-2.72 * * *$ & -3.02 & 100.0 & $-3.31 * * *$ & -2.79 & 100.0 & $-3.87 * * *$ & -2.68 & 100.0 \\
\hline
\end{tabular}




\section{Table X}

\section{Panel B: Contagion Effect of AIG's Distress on Unsecured Creditor's Stock Prices}

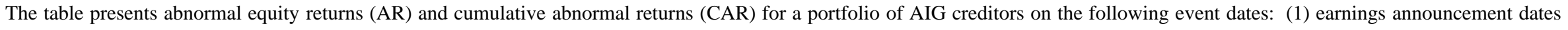

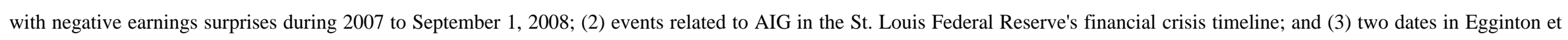

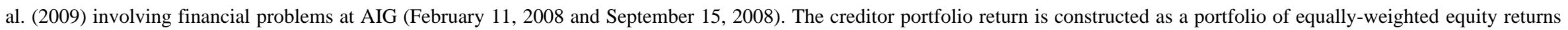

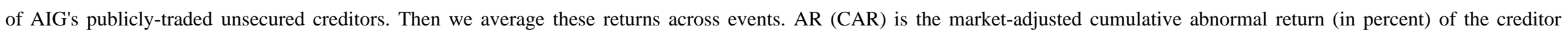

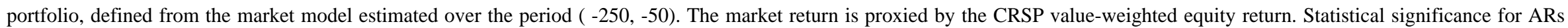

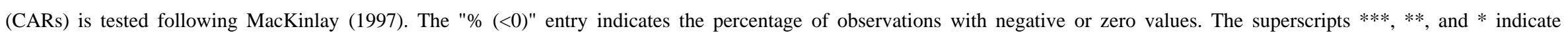
significance at $1 \%, 5 \%$ and $10 \%$ levels, respectively.

\begin{tabular}{|c|c|c|c|c|c|c|c|c|c|c|c|c|}
\hline \multirow[b]{2}{*}{ Day } & \multicolumn{3}{|c|}{6 Significant Negative Events before Bailout } & \multicolumn{3}{|c|}{ Distress Day } & \multicolumn{3}{|c|}{ Creditors with High Exposure/TA Ratio } & \multicolumn{3}{|c|}{ Creditors with High Exposure/Equity Ratio } \\
\hline & Mean (\%) & T-stat. & $\%<0$ & Mean (\%) & T-stat. & $\%<0$ & Mean (\%) & T-statistic & $\%(<0)$ & Mean (\%) & T-statistic & $\%(<0)$ \\
\hline-2 & -0.63 & -1.16 & 66.7 & $-2.27 * * *$ & -3.77 & 92.9 & -0.78 & -1.42 & 66.7 & -0.81 & -1.35 & 66.7 \\
\hline-1 & -0.28 & -0.69 & 66.7 & -0.53 & -0.83 & 57.1 & -0.18 & -0.43 & 50.0 & -0.35 & -0.68 & 50.0 \\
\hline 0 & $-1.89 * * *$ & -4.43 & 100.0 & $-3.94 * * *$ & -3.22 & 85.7 & $-2.14 * * *$ & -4.10 & 100.0 & $-2.31 * * *$ & -3.39 & 100.0 \\
\hline 1 & -0.45 & -1.07 & 66.7 & -2.32 & -1.34 & 57.1 & $-0.61 * *$ & -2.28 & 83.3 & $-0.72 * * *$ & -2.93 & 100.0 \\
\hline 2 & -0.99 & -1.62 & 66.7 & $-3.90 * * *$ & -2.81 & 78.6 & $-0.76^{* *}$ & -1.69 & 66.7 & $-0.90 *$ & -1.74 & 83.3 \\
\hline 0,1 & $-2.34 * * *$ & -2.86 & 100.0 & $-6.26^{* * *}$ & -3.21 & 85.7 & $-2.75^{* * *}$ & -3.73 & 100.0 & $-3.02 * * *$ & -3.59 & 100.0 \\
\hline$-1,1$ & $-2.62 * * *$ & -2.92 & 100.0 & $-6.79 * * *$ & -3.09 & 64.3 & $-2.93 * * *$ & -3.41 & 100.0 & $-3.37 * * *$ & -3.23 & 100.0 \\
\hline$-2,2$ & $-4.24^{* *}$ & -2.34 & 100.0 & $-12.96 * * *$ & -3.59 & 78.6 & $-4.47 * * *$ & -2.73 & 100.0 & $-5.08 * * *$ & -2.71 & 100.0 \\
\hline
\end{tabular}

